SAD / JSR

Sosyoloji Araştırmaları Dergisi / Journal of Sociological Research

Cilt / Volume 22 Sayı / Number 2 (Ekim / October 2019) : (124-182)
Araştırma Makelesi / Research Article

Geliş Tarihi / Submited: 09.01.2019

Kabul Tarihi / Accepted: 02.08.2019

\title{
POSTMODERN ZAMANLARDA ATALAR KÜLTÜ: SOSYAL MEDYADAKİ SOYAĞACI PAYLAŞIMLARI ÜZERİNE BİR DEĞERLENDİRME ${ }^{1}$
}

Kadir ŞAHİN ${ }^{2}$

\section{ÖZ}

Modernite öncesindeki geleneksel toplumlarda hayatı inşa eden stratejiler geçmişin üzerine kurgulanmaktaydı. Bu yüzden atalar, soy, şecere ya da soyağacı gibi kavramlar bireyler için çok daha önemliydi. Ayrıca bu tarz kavramlar, ölümlü bireylere kendilerini aşkın bir gerçekliğin parçası olma imkanını sağladığı için, onları ölümsüzlügü olan stratejilere entegre etmekteydi. Bireyleri toplumsal ortaklıklarda “iz bırakmak" üzere aktifleşmeye davet eden bu türden yapılar, hayata dair de anlamlı istikrar anlatıları sunmaktaydı. Fakat geç modern (postmodern) bireylerin içinde bulunduğu birliktelikler giderek “özerk stratejilerin” belirginleștiği hayatlar haline geldi. Böylesi hayatlar geleceğin belirsizliğinde kurgulandığı için, geleneksellik (geçmiş) ya da kalıcı anlatı biçimleri bu evredeki "gelenek ötesi bireyler" için anlamını yitirmektedirler. Bu çalışmanın amacı; bir atalarla karşılama biçimi olarak, sosyal medyadaki “soyağacı gündemi” üzerinden postmodern bireylerin hayatındaki geçmiş ve gelecekle ilişki kurma biçimlerini anlamlandırılabilir hale getirmektir. $\mathrm{Bu}$ sayede gündemin neden parodik içerikler kazandığına dair cevaplar üretebilmek de mümkün hale gelebilmektedir. Yakın zaman öncesinde Türkiye'de, "e-Devlet” üzerinden erişime açılan soyağacı hizmetine toplumun önemli bir kesimi yoğun ilgi göstermişti ve sosyal medya üzerinden büyük bir gündem üretilmişti. Çalışma, yaşanan gündemi “nitel” boyutlarda sürdürülen bir "vaka incelemesi”" olarak irdelemeye çalışmış ve ortaya çıkan toplumsal davranış biçimini geç modern zamanlardaki "belirsizlikler ve ölüm korkusunun” dışavurumu olarak anlamlandırmaya çalışmıştır.

Anahtar Kavramlar: Premodern Hayat, Modern Hayat, Postmodern (Geç Modern) Hayat, Atalar Kültü, Ölümsüzlük Stratejisi, Belirsizlikler ve Ölüm Korkusu, Soyağacı Paylaşımları.

\footnotetext{
${ }^{1}$ Bu çalışma 4-5 Mayıs 2018 tarihlerinde Adana'da düzenlenen II. Multidisipliner Çalışmaları Kongresi'nde sunulan bildirinin genişletilmiş halidir.

${ }^{2}$ Dr. Öğr. Üyesi, Karabük Üniversitesi Edebiyat Fakültesi, Sosyoloji Bölümü

SAD / JSR

Cilt / Volume 22 Sayı / Number 2
} 


\title{
THE CULT OF ANCESTORS IN POSTMODERN TIMES: AN EVALUATION ON GENEALOGY SHARES ON SOCIAL MEDIA
}

\begin{abstract}
In traditional societies of pre-modern era, the strategies constituting life used to be built on the past. Besides, since such concepts allow mortal individuals to become a part of a reality beyond them, they used to integrate mortal individuals into immortal strategies. Such entities which invite individuals to act up so as to 'leave a mark' in the societal commonalities also presented meaningful narratives about life. However, the associations of late modern (postmodern) individuals have gradually become lives in which 'individualistic strategies' are prominent. Since such a way of life is built on the uncertainties of the future, no form of traditionalism (the past) or permanent narrative styles is meaningful for the 'post traditional individuals' in that phase. The purpose of this study, as a way encounter with ancestors is to be able to make sense of the relationship between past and future in the life of postmodern individuals through the family tree agenda in social media. In this way, it is possible to produce answers to why the agenda has gained parodic content. Before recently in Turkey a significiant portion of the society has shown great interest to access services over the e-Governement opened pedigree and was produced a huge agenda through the social media. The study has tried to examine the agenda as a 'case study', and interpret the emergent public behaviour as an expression of the 'uncertainties and fear of death' in the late modern era.
\end{abstract}

Key Words: Premodern Life, "Modern Life", "Postmodern (Late Modern) Life", Ancestry Cult, Immortality Strategy, Uncertainties, Family Tree Sharing. 


\section{GİRISS}

Warner Bros. yapımı 'Forever' (Sonsuza Kadar) adlı bir dizi 2015 tarihinde Amerika'da gösterime girmişti. ${ }^{3}$ Dizinin başrol karakterini oynayan Dr. Hanry Morgan (Ioan Gruffudd) 200 yaşında ama gayet genç görünen (her zaman 33 yaşında) ve her öldüğünde aynı görünümüyle suyun içinde canlanan bir karakteri oynamaktayd1. Dizi Amerika'da ve dünyada iyi bir izleyici kitlesine erişti. Şüphesiz dizinin ilgi çekici teması ve senaristlerin sürüklemek istedikleri kurgunun içerisindeki ana odak nokta 'ölümsüzlük' vurgusu olmaktaydı. Böyle bir kurgunun ilgi çekici olması, içinde yaşadığımız dünyanın sahip olduğu (aslında buna sahip olmadığ 1 demek daha yerinde bir tabir olacaktır) gerçekliklerden kaynaklıdır. Dizinin 15. bölümünün girişinde (02' 40" - 03' 00") kısa bir sahnede Dr. Hanry Morgan'ın sesinden, 'iç ses' biçiminde bir konuşma verilmektedir:

Neden kendi atalarımızı bulmak zorunda hissederiz? Soyağacımızdaki isimler yalnızca isimden ibarettir. Buna rağmen onlara karşı hissettiğimiz yakınlık çok güçlüdür. Çünkü kadim (köklü) bir geçmiş bizi kendimize daha mı güvende hissettirir? Ya soyağaçlarımız! Asmalar misali çağlar boyu amaçsızca sarmalanmışsa? (Forever 15. bölüm: 02' 40" - 03' 00").

Dizide bir ölümsüzü oynayan karakterin ağzından böyle bir pasajın veriliyor olması şüphesiz seyircinin kendisine dair hissettikleriyle ilgili bir vurgulama biçimidir. Çünkü ölümsüz bir karakterin izleyiciye ifade ettiği şey, içinde bulunulan dünyadan hiç gitmiyor olmasıdır ya da başka bir ifadeyle bu dünyayı hiç terk etmiyor olmasıdır. Ayrıca ölümsüz birinin hayatını kurgulayan temeldeki şeylerden birisi onun sahip olduğu uzunca geçmişidir. Dizide, Hanry Morgan'ın hayatına dair taşımakta olduğu 'büyük hafizası', onun yaşadığı şimdiki hayatının merkezi noktasını her defasında kendi geçmişinin izleri içinden çıkarmasına imkan sağlamaktadır. Çünkü Hanry Morgan'ın hayatının merkezinde geçmişi vardır ve gelecek onun

${ }^{3}$ Miller, M. (2015). Forever (15. Bölüm: 02"40' - 03'00'), California: Warner Bros.. 
ölümsüzlügünden ötürü hiçbir kayg1 ya da belirsizlik faktörü üretememektedir. Nitekim dizinin şimdiki zaman kurgusunda, Hanry Morgan'ın hafızasında (ya da yaşamında) sürekli geçmişe gidiliyor olması da aslında bunun sonucundaki neden olmaktadır. Onun kaygıları hep geçmiştedir. Fakat böylesi bir karakterin ağzından "biz" diyerek dökülen cümleler temelde 'biz ölümlüler' için sarf edilmiş ve aslında onun kendisini merkeze koymayan cümleler niteliğindedir. Çünkü Hanry Morgan sıradan olanın aksine 'özeldir' ve rastlanması imkansız olan bir istisnayı canlandırmaktadır. Bir bakıma Olimpos Tanrılarının yeryüzüne teşrif etmiş halleri gibidir: 'İnsan görünümlü' (zaten insan), 'insani doğaya sahip' (anthrepophyeis) fakat Arendt'in tabiriyle söylersek (2013) bu dünyayı hiç terk etmeyecek olmasından ötürü 'ölümsüz' biridir. Onun burada "biz" diyerek başladığı cümleler aslında dizinin izleyicisi olan kitleler içindir: Yani buradaki 'biz' olanlar kendisinin zıttı olan 'ölümlülerdir'.

Hanry Morgan'ın dizi boyunca vurgusunu yaptı̆̆ı şeyler aynı zamanda geç modern (postmodern) bireylerin, çoğunlukla bilinç düzeyinde yüzleşmek zorunda kaldığı duygulardır. Çünkü Spellman'ın (2017, s.14) tabiriyle söylersek "herkes ölür biliyoruz". Bu bakımdan 'soy' ya da 'soyağacı' (şecere) bireyler için sadece bir isim yı̆̆ını ya da amaçsız bir gösterge değildir. Bireyi insani duyguları açısından aşkın gerçekliklere ve hatta toplumsallıklara bağlamaktadır. Böylesi araçlar bireyin dünyada sıklıkla hissettiği geçiciliğe karşılık, kalıcılık hissi yükleyen duygu biçimleri olmaktadır. Bu sayede yaşanılan hayat bireyler için ömürlerini aşkın bir bağlama erişerek, onların geçiciliklerini (faniliklerini) anlamlı hale getiren bir sürece dönüşmektedir. Soyağacı üzerine bireylerin hissettiği tarihsel yakınlık (atalarına olan yakınlık) onlara köklü bir geçmişin parçası olmak açısından 'güvenlik' -ontolojik güvenlik demek daha yerinde olur- duygusu vermektedir. Nitekim geçmişin ürünü bir gelenek de bu yüzden bireylerin hayatında oldukça değerli bir araçtır.

Gelenek rutindir. Ancak yalnızca öylesine sürdürülen boş bir alışkanlık olmasından çok, aslî olarak anlamlı olan bir rutindir... Özetle gelenek, güveni; geçmiş, şimdi ve geleceğin sürekliliğinde 
sürdürdüğü ve bu tür bir güveni rutinleşmiş toplumsal uygulamalara bağladığı sürece, ontolojik güvenliğe temel bir biçimde katkıda bulunur (Giddens, 2004, s.106).

\subsection{Sosyal Medyadaki Görünürlüğü Açısından “Soyağacı Gündemi” ve Araştırmanın Yöntemsel Açıdan Kurgulanma Biçimi}

Türkiye, 2018'in Şubat ayı ile birlikte, 'soyağacı' gündemini oldukça yoğun bir tartışma konusu haline getirmişti. Bu tartışma bir 'e-devlet' hizmeti olan 'soyağacıyla' ilgili yapılan sosyal medya paylaşımlardan kaynaklıydı. Şubat ve Mart aylarının büyük bir kısmında gündemden düşmeyen şekilleriyle, hatta başlangıcında belli bir dönem interneti kilitleyecek bir yoğunlukla birlikte, bir sosyal medya furyasına dönüşmüştü. Öyle ki sosyal medyadaki paylaşımlarda, başlarda güvenliğe hiç uymayan şekillerde, bireylerin tüm özel bilgilerinin kendileri tarafindan (TC kimlik numarası ve anne kızlık soyadı gibi) kamusala ilan edildiği de görülmekteydi. Fakat gündem kısa bir süre içinde, çok büyük ilgi görme biçimine karş1lık, giderek parodik içerikler kazanmıştı. Çünkü paylaşımlar, 'postmodern' bireylerin 'kendi soyağaçlarındaki ataları' üzerinden güldürü üretmelerine neden olan paylaşım biçimlerine dönüşmüştü. Gündemin önemli görülme biçiminin aksine, sosyal medyadaki mevcut duruma rağmen, böylesi parodik bir dile erişmesinin kendi içindeki sergilediği tutarlık onu 'özel bir niteliğe taşıyarak' derinlemesine tahlile açık bir 'örnek olay/vaka' haline getirmekteydi. Bir bakıma yaşananlar geç modern bireylerin "gelenek ötesi" (Giddens, 2004) olan hayatlarındaki 'geçmiş', 'gelenek', 'atalar kültü' ve 'ölümsüzlük stratejisi' açısından çok önemli detaylar taşımaktaydı. Çünkü söz konusu gündem onların ölümü deneyimle (ya da ölümsüzlügü yapısöküme uğratma) biçimini, yaşadıkları 'belirsizlikler ve korkular' açısından açık eden niteliklerdeydi. Bu nedenle de gerçekleşme şekli ve içeriği açısından anlamlandırılması gereken önemli içeriklere sahip olmaktayd1.

Öncelikle belirtilmesi gereken önemli bir nokta, çalışmanın amacı 'soyağacının' ne olduğuna dair bir açıklama getirmek değildir. Çalışma boyunca irdeleme çabasında olunan temel nokta; hayatın 'ölümle ilişkisi' bağlamında yaşadığı dönüşümü 'soyağacı gündemi' ve içerisinde barındırdığı 'atalar kültü' özelinde 
'nitel boyutlarıyla' tartışabilmek ve bu sayede de gündeme içkin olarak ortaya çıkan durumu derinlemesine anlamlandırabilmektir. Çünkü tartışma tarafımızca, yaşananların temelde 'ölüm ve ölümsüzlük' bağlamında; geç modern evrede ortaya çıkan 'korku ve belirsizlik' temasının dışında bir çıktı olmadı̆̆ı üzerine kurgulanmıştır. Nitekim bir nitel sorgulama biçimi olarak ele alınan 'vaka analizi'; araştırmacının kendi öznel kurgusunu yansıtmaktadır (Merriam, 2013; Yin, 2017) ve bu türden çalışmaların da öncelikli amacı yaşananların nelere tekabül ettiğinin anlamlandırılması olmaktadır (Davey, 2009). Bu bakımdan 'soyağacı tartışması' bizler için, tarihselliği çok daha geniş olan 'ölüm korkusunun' ve bunun ürünü olan 'atalar kültüne' dair günümüzdeki gelinen noktanın toplumsal izdüşümlerini anlayabilmek için önemli içerikler barındırmaktaydı. Görünürlük kazanan olay, postmodern zamanlara özgü gündelik hayata dair yansımalar niteliğindeydi. Bu açıdan ortaya konulmak istenen detaylandırmalar için soy ağacı gündemi bir 'örnek olay' (vaka analizi) anlamı taşımakta ve bu yönde kurgulanmaktaydı. Nitekim çalışma boyunca 'soyağacı' ve 'soyağacı gündemi' bağlamında ele alınan konu, 'geçmişin yitirilmesi bağlamındaki belirsizliği', insan tarihinin 'ölümsüzlük stratejileri' bağlamında yaşadığı dönüşümleri es geçmeden yapmaktadır. Buradan hareketle de çalışmanın temel kaygısını; ortaya çıkan 'vakanın' tarihselliğine uygun teorik açıklama zeminini inşa edebilmek ve bu sayede yaşananların olgusallığına dair bir düşünsel arka plan üretebilmek olmaktadır. Nitekim Merriam'ın (2013) da dediği gibi "bir vaka çalışmasının içinde örtük olan bir teori inşa edilebilir ya da bir vaka çalışmasının verileri eleştirel teori perspektifiyle analiz edilebilir" (s.42). Bu bakımdan "vaka çalışmasında... bir olgunun geçmişi anlatılmakta ya da ayrıntılarıyla incelenmektedir... Sınırlı bir sistem ya da vaka, belirli bir sürecin, konunun ya da kaygının bir kesiti olduğu için seçilebilir" (Merriam, 2013, s.39-41). Bu bakımdan çalışmanın, tarihsel perspektifi dikkate alınarak, teorik bir zeminin inşa edilme çabasında olunacağını da şimdiden dile getirmek yerinde olacaktır. Bu nedenle okuyucunun düşünsel olarak içine çekilmek istendiği noktadan hareketle, ilerleyen kısımlarda 'araştırmanın bulguları ve yorumlanması' şeklinde bir başlık ortaya konulmayacaktır. Fakat olgusallığa dair üretilmek istenen perspektif boyunca ortaya konulacak teorik tartışmanın her aşamasında 'soyağacı 
gündemine' gönderme yapılacak ve özellikle de "Postmodern Toplumlardaki 'Özerk Stratejiler', 'Ölümsüzlügün Evcilleşmesi' ve Parodikleşen Soyağacı Gündemi' başlığında (2.3.'te) ortaya konulan teorik tartışmaya, gündeme dair örnekler de sunularak tartışma somutlaştırılmaya ve de içinde barındırdıkları yönüyle anlamlandırılmaya çalışılacaktır.

Burada tartışma açısından vurgulanması gereken bir başka önemli nokta: Oluşan yoğun gündem çerçevesindeki sosyal medya paylaşımlarında tek boyutlu bir görünürlüğün (paylaşım tipinin) söz konusu olmamasıydı. Bu çalışma kapsamında dikkate alınan türden 'paylaşımların' dışında da soyağaçları kitlelerce gündemleştirilmekteydiler. Tüm 'sosyal medya paylaşımları' dikkate alındığında, görünürlük biçimleri açısından kabaca üç temel başlık altında toplanabilecek paylaşım tipi dikkati çekmekteydi. Fakat paylaşımların en yoğun görünürlük biçimi ise bu çalışmanın kapsamında tartışılmaya çalışılan şekliydi. Bu tarz paylaşımlar, bireylerin kendi geçmişiyle kurduğu ilişkinin, tarihsel beklentilerin dışındaki gayri ciddi (alaya alınan) biçimde gerçekleşen haliydi. Diğer iki tip paylaşım türü ise daha çok siyasi şekillerde (seçim gündemi ve resmi devlet söylemiyle ilişkilendirilerek) ifade edilen paylaşım tipleriydi. Fakat çalışmanın bağlamına uygun olarak, en çok gündeme gelen şekli; yani parodik olarak görünürlük kazanan atalarla (geçmişle) karşılaşma hali, tarafımızca irdelenmek üzere çalışma kapsamında sınırlandırılan ve tartışmaya açılan 'özel örnekleme' biçimleri olmaktaydı. Çünkü 'vaka analizi' kapsamında irdelenmek istenen olay belirli bir amaca dönük 'özel veri grubunu' inşa etmeyi gerektirmekteydi (Maxwell, 2005). Nitekim bu tarz paylaşımların 'tarihsel bağlama' özgü yorumlanabilirliğine dair sahip olduğu arka plan, bir 'vaka/durum çalışması' olarak tarafımızca değerli görülmelerine ve bu nedenle de başlı başına dikkate alınmalarına neden olmaktaydı. Böylesi bir seçicilik ve sınırlandırmayla paylaşım biçimlerinden 'amaçlı örnekleme grubu' inşa etmekte çalışma açısından herhangi bir sakınca görülmemiş̧tir. Çünkü "durum (vaka) çalışması araştırması özel bir durumun belirlenmesiyle başlar... doğru bilgiyi toplayabilmek için, sürmekte olan güncel, gerçek yaşam durumları üzerinde çalışırlar" (Creswell, 2016b, s.98). Ayrıca "bir vaka çalışmasında... araştırmacı, araştırma esnasında çabasının büyük bir kısmında kendi içgüdülerine ve yeteneklerine güvenmek 
zorundadır" (Merriam, 2013, s.50-52) ve verilerini de bu yönde inşa etmek durumundadır. Nitekim Yin'in (2017) de vurguladığı gibi "olay ve gerçek yaşam arasındaki bağ açık olmadığından, aralarında nedensel bağ olduğu düşünülen (varsayılan) olayları tutarlı bir zeminde açıklayabilmek" şeklinde bir kaygımız vardı. Bu nedenle de yaşanan gündemin bir 'durum/vaka çalışmasına' (ya da örnek olay incelemesine) özgü şekillerde kurgulanmasında herhangi bir sakınca görülmemiştir. Bu nedenle tartışma -daha önce de ifade edilen şekliyle- "neden parodikleşti?" noktasında mevcut gündeme dayalı olarak kurgulanmış ve tarihsel bağlamını dikkate alan bir şekilde sorunsallaştırılmıştır.

Çalışmada 'giriş' bölümü dışında ortaya konulan diğer bölüm (ikinci bölüm) üç temel alt başlık etrafinda kurgulanmıştır. Bu üç alt başlığın tartışmayı inşa eden perspektifi, 'geçmiş' ve 'atalar kültü' bağlamında toplumların 'ölüm ve ölümsüzlükle' ilişki kurma biçimini merkeze koymaktadır. Söz konusu tartışmanın ilk alt bölümünde (2.1.'de) söz konusu bağlamı modern öncesi (premodern) toplumlardaki görünürlüğü üzerinden tartışırken, ikinci alt başlıkta (2.2.) tartışmanın modern toplumlardaki görülme şekli ortaya konulmaktadır. Üçüncü alt başlık ise (2.3.) yaşananların günümüz bağlamındaki iz düşümlerini postmodern zamanlardaki çıktıları olarak tartışmaktadır. Bu bölümde postmodern bireyin geçmişle, gelecekle ve bunun ürünü olarak da atalarla ilişkiselliği 'soy ağacı' gündeminde elde edilen sosyal medya paylaşımları etrafında detaylandırılmaktadır. Bu sayede de söz konusu gündemde ortaya çıkan 'parodik temelli' paylaşımların nedenleri ve görünenin ardındaki detaylar ortaya konularak anlamlandırılmaya çalışılmaktadır.

\subsection{Araştırmaya Dair Veri Toplama Tekniği}

Çalışma boyunca dikkate alınan veri grubu, yukarıda Creswell'den hareketle ifade edilen şekliyle; yaşanan gündemin "özel bir durum" olmasına karar verilmesinin ardından, "sürmekte olan güncel ve gerçek bir yaşam durumu üzerinden veri derlemesine girişilerek" gerçekleştirilmekteydi. Bu nedenle de 'araştırmaya konu özel örnekleme' yeteneği olanlar, söz konusu tarihlerdeki (olayın akış anındaki) sosyal medya ortamında yapılan paylaşımlar üzerinden 15 Şubat ve 5 Mart 2018 tarihleri arasında derlendiler. İrdelemeye 
konu olan paylaşımlar Twitter, Facebook, Instagram gibi sosyal medya ortamlarında karşılaşılanlar üzerinden elde edilmişlerdir. Bu tarz paylaşımlar veri amaçlı toplanırken, çalışmanın 'özel hayatın gizliliği ilkesini' ihlal etmemesi açısından, 'herkese açık' şekilde yapılan paylaşımlardan derlenmesine ayrıca dikkat edilmiştir. Ayrıca olayın gerçekleşme tarihlerinde bahsi geçen sosyal medya ortamlarındaki "herkese açık" şekilde yapılan paylaşım tiplerini belli 'anahtar kavramlar' ('soyağacı', 'soy ağacı', 'e devlet' vb.) vasıtasıyla aramak ve kendilerine erişmek ilgili sosyal medya ortamlarında zaten mümkün olabilmekteydi. Gündemin yoğunluğuna bağlı olarak sayıları binleri bulan paylaşımların tamamının çalışma kapsamında görselleştirilerek kullanılması mümkün olmadığı için, içlerinden ilgili bağlama özgü temaları yansıtmaları kaydıyla, kesitsel göndermeler sunmaya imkan verebilecek nitelikte olanları seçilerek tartışma boyunca görselleştirilmişlerdir. Her ne kadar 'özel örnekleme tekniği' kapsamında derlenen örnekler, herkese açık paylaşımlar şeklinde olsalar bile, kişisel verilerin güvenliğine aykırı kullanımlar olmamasına da tarafımızca ayrıca dikkat edilmiştir. Bu tarz bir filtrelemeye rağmen kullanıcı hesaplarının ifşa edilmemesi için, çalışma boyunca kolajlar şeklinde kullanılan görsellerdeki isimler ve adresler karartılarak görünürlüklerinin engellenmesi gereklilik olarak görülmüş ve paylaşımların okuyucuya bu şekilde sunulmasına ayrıca özen gösterilmiştir.

\section{GELENEKSEL TOPLUMLARDAN POSTMODERN TOPLUMLARA “ÖLÜMLÜLÜK”VE “ÖLÜMSÜZLÜK” DENKLEMİNDE GEÇMİŞ VE GELECEK}

İnsanlar kadimsellik, süreklilik, aşkınlık gibi konulara her zaman ziyadesiyle ilgi göstermişlerdir. Ayrıca insanlık tarih boyunca ölümsüzlük meselesiyle de oldukça fazla ilgilenmiştir. Tarihsel gerçeklikler dikkate alındığında, ölümlülük ya da ölümsüzlüğün çoğunlukla atalar kültü ve geleneklerle ilişkili bir açıklama zemini olduğu dikkati çekmektedir. Çünkü her bireyin dünyaya dair yaşadığı hayatın en büyük problemlerinden birisi ölüm ya da ölümlülüğün kendisi olmuştur.

$\mathrm{SAD} / \mathrm{JSR}$

Cilt / Volume 22 Sayı / Number 2 
Ölüm; geri döndürülemez olandır... Ama ölümle birlikte neye açılıyoruz; yokluğa mı, yoksa bilinmeyene mi?... Ölüm yanıt yokluğudur... Sadece bir varlığın bitmesi, yok olması, aynı zamanda gösterge değeri taşıyan bütün hareketlerin durması vardır... Yine de ölümün kesinlik demek olduğu kesin değildir ve ölümün yok olma anlamına gelmesi de kesin değildir (Levinas, 2014, s.11-13).

İnsanlık, ölüme endeksli yaşadığı hayatlarda, doğaya sınırsız düzeyde müdahalelerde bulunmayı kendisine bir hak olarak görmüştür. Geçtiğimiz yüzyılda uzaya araç yollamanın ve organizma üretebilmenin insana yüklediği kozmik/semavi yetenek algısı, giderek onun 'insanlık durumundan' kurtulmasını mümkün kılacak 'yaratıcılık' hislerini güçlendirmiştir. Bu yüzden 'insanlık' dünyayı yok etmedeki inancını artık yaratıcılık konusunda da gösterir hale gelmiştir (Arendt, 2013, s.27-30). İnsanlığg son derece önemli olan bu eşik değere taşıyan en önemli nokta, onun kendisine dair yaptığı bu büyük keşiften kaynaklıydı. İnsanın kendi doğasına dair anladığı ve diğer canlıların farkına varamadığı bu önemli keşfini anlamlı kılan çıkış noktası, onun farkına vardığı bir başka çok önemli buluşunun sonucudur: O da 'ölümlülüktür' (Heidegger, 2011). Bu keşif (ölüm korkusu) aslında onun kendisine dair var olan 'tarihsel huzursuzluğunun' da nedenidir. Yaşananlar bir bakıma bu büyük keşfi boşa çıkaran nitelikteydi (Arendt, 2013) ama 'ölüm' evrensel, kaçınılmaz ve herkesi bekleyen yegane olgudur. İnsan, geçiciliğinin farkında olan ve ondan kaçılamayacağını bilen de tek canlıdır. Onun sonsuzluğu hayal edebilmesini sağlayan şey ölüme dair bu türden farkındalığıdır (Heidegger, 2011).

İnsanın ölüme dair bu farkındalığı ve kaçınılmazlığı aynı zamanda onun sonsuzluğu hayal edebilmesini sağlayan itici gücüdür (Kierkegaard, 2004). Çünkü "ölüm... her türlü imkanı mümkün kılan bir imkandır" (Levinas, 2014, s.58). Kültür ise bireylere bu yöndeki açıklayıcı ve çoğu zaman da avutucu cevapları veren olmazsa olmaz bir gerçekliktir. "Aslında ölümsüzlük sadece elden geldiğince uzaklaştırılmış bir ölüm olur" (Feuerbach, 2015, s.183). Kültürün bu noktadaki yaptığı şey ise 'ölümün gölgesinde' (ölüm korkusuyla) yaşanan hayata dair bazı stratejiler verebiliyor olmasıdır (Bauman, 2012a, s.40-42). Ölüm ne her şeyin sonu 
ne de sonsuz yaşam içindeki basit bir öyküdür. İnsan; sonsuzluk ile sonlunun, geçicilik ile kalıcılığın, özgürlük ile zorunluluğun bir sentezidir. Kısaca 'insan olmanın kendisi bir sentezdir'. Bu açıdan insanı, ölüm ve ölümsüzlük bağlamındaki denklemde ilişkisel kılan şey yaşamın kendisidir. 'İnsanî bir hayat' bireyi, aşkın olan gerçekliklere açık hale getirmektedir. Bu yüzden ölüm bir son değil, insanı büyük bir sonsuzluğun parçası yapması muhtemel bir eşiktir (Kierkegaard, 2004, s. 19-24). Ölümlü (fani) bireylerin hayatı bir bakıma sonsuzluk imgelerini içinde barındırdığı için bir anlama sahiptir. Bu yüzden "ölüme, basitçe hayatın sonlanması olarak yaklaşan kültür neredeyse yok denecek kadar azdır" (Spellman, 2017, s.16). Bireyler de bu türlü vurgulara dair referanslar üretebilmek adına geçmişlerine ve de atalarına tarih boyunca yoğun bağl1lıklar geliştirmişlerdir. "Aristoteles, "Beşeri meseleler ele alınırken, insan olduğu gibi görülmemeli, ölümlü olana bakılmamalıdır, tersine onları ölümsüzlük açısından taşıdıkları potansiyele göre düşünmek gerekir", sözlerini yeri geldikçe tekrarlar" (Arendt, 2013, s.100). Bu bakımdan soyağaçları gibisinden atalarla (geçmişle) ilişki kurmayı sağlayan araçlar, bireylere ölümlü hayat içindeki sonlu ömürleri aşkın zamansallıklar vaat etmesi açısından önemli bir strateji (hatta ölümsüzlük stratejisi) sunabilen niteliktedir.

Hayat değerini ölüme borçludur... sırf ölümlü olduğumuz için günleri sayarız ve günler sayılıdır... biz insanlar ölümlülüğümüzün farkında olduğumuz için hayat değer taşır ve günlerin ağırlığı vardır. Ölmemiz gerektiğini ve hayatımızın, Martin Heiddegger'den alıntıyla, 'ölüme kadar yaşamak anlamına geldiğini' biliriz... Eğer hayatın kırılganlığına ya da sonluluğuna ilişkin bilgiye kalıcılık ve sonsuzluk karşısında üstün değer verilmiş olmasaydı, ölümün kaçınılmaz olduğunu fark etmek hayatı kolayca değerden yoksun bırakabilirdi (Bauman, 2011, s.288).

İnsanlık tarihsel süreç içinde uzunca bir dönem, kendisini ve varlığını geçmişiyle/atalarıyla ve ölümle kurduğu kadim ilişkiler üzerinden anlamlandırmaktaydı. Geçmişteki toplulukların atalarıyla kurduğu köklü ilişkilerin boyutu her zaman saygı, güvenlik ve kutsallıkla birlikte karşılık bulan bir bağlama sahipti 
(Kerrigan, 2018, s.116-123). Hatta geçmişteki geleneksel (premodern) ${ }^{4}$ toplumlarda, atalara tapmak sıkça rastlanan sıradan bir davranıştı (Frazer, 2017; Coulanges, 2011). Bu bakımdan soy ve soyağaçları; bireylerin kendilerini sosyal açıdan ifade etme aracı olduğu kadar, kendilerine ontolojik güvenlik mekanizmaları da sunan nitelikteydi. Bir bakıma 'geleneksel (premodern) topluluklar', hayatlarının istikrarını atalarına bağlılıkları çerçevesinde kurgulamaktaydı.

İçinde bulunulan 'postmodern zamanlar' dikkate alınınca, aslında yukarıdaki vurgular için, "geçmişte güvenlik verirdi" diyerek yaklaşmak daha yerinde olacaktır. $\mathrm{Bu}$ nedenle çalışma kapsamında sorunsallaştırılmaya çalışılan nokta; atalarıyla (geçmişleriyle) kadim ilişkilerini yitiren günümüzdeki postmodern bireylerin, söz konusu soyağacı gündemi dahilinde verdiği tepki ve geçmişle kurduğu ilişki biçiminin niteliğini sorgulayabilmek olmaktadır. Çünkü postmodern bireyler söz konusu gündem dahilinde atalarıyla (geçmişleriyle) ilgili bir bilgi ya da referansa (soyağacına hizmetine) erişirken -Hobsbawn'ın (2001) ifade ettiğinin aksine- ${ }^{5}$ onlara tarihsel bağl1lıklar ilan etmek ya da saygı kriterini işletmektense, onları daha çok parodik şekillerde gündemleştirmişlerdir.

Yaşanan gündemi böylesi bir kurguyla anlamlandırabilmek tarihsel dönüşümü dikkate alan tahlillere de ihtiyaç duymaktadır. Bunu yapabilmek adına karşımıza çıkan gündemi/gerçekliği Husserl'in tabiriyle (2010) eylemsel olanı bir kesinlik olarak algılamayı 'askıya alarak'- görünenin ötesindeki iz düşümlerde aramak bir gereklilik olarak görülmüştür. Çünkü söz konusu gündem, tarihsel temeldeki beklentilerin dışında görünürlük kazanınca, ortaya çıkan toplumsal davranış biçiminin, tarihsel süreci de merkeze koyan

\footnotetext{
${ }^{4}$ Metin boyunca kullanılan premodern tabiri, modernite öncesindeki İbrahimi kurguların ürünü olan kamusal alanları ve de onun ürünü hayatı karşılamak adına kullanılmaktadır. Aynı evreye metin boyunca 'geleneksel evre' demekten de sakınılmamıștır. Buradaki vurgulama Antik dönem kamusalını kapsayan bir kavramlaştırma biçimi değildir.

${ }^{5}$ Hobsbawn geçmişin; gerek 'gelenek' olarak gerekse 'atalar-kültü' (geçmiş ya da ölmüşler) bağlamında 'bugün' üzerinde güçlü bir etkisi olduğunu ve bunu soyağacı oluşturma çabalarında görmenin de mümkün olduğunu ifade etmektedir ve ölmüşlerle olan bağlarımızı ortaya koyan soyağaçlarının okuryazar toplumlar için ayrıca önemli olduğunu dile getirir (s.33-36).
}

$\mathrm{SAD} / \mathrm{JSR}$

Cilt / Volume 22 Sayı / Number 2 
teorik temeldeki anlamlandırılması önemli hâle gelmekteydi. Tartışma boyunca 'gelenek ötesileşme' sürecinin merkeze konulma nedeni de 'soyağac1' perspektifindeki tartışmanın, 'geçmişin hükümsüzleşmesini' açık eden niteliklerde olmasından kaynaklıydı. Çünkü geleneksel ve modern evrede gündelik hayatın merkezinde 'geçmiş referanslar' (ve dolayısıyla atalar) bulunmaktaydı ve bu nedenle geçmiş çok önemli olmaktaydı. Fakat gelenek ötesi olan geç modern toplumlarda, bugünün merkezini belirleyen şey gelecektir (Beck, 2011). Bu nedenle atalar kültü, soy ve şecere mukabilinden gerçeklikler burada, önceki dönemde sahip oldukları anlamlarını yitiren kültürel araçlar niteliğine bürünmüş durumdadırlar. $\mathrm{Bu}$ yüzden eski işlevi, misyonu ve anlamından çok uzakta gerçeklikler niteliğinde görünürlükler kazanmaktadır. Nitekim yaşanan gündemi, bir 'vakâ çalışması' olarak değerlendirilmeye açık hale getiren önemli nokta, modernleşmenin şiddetlenmesiyle birlikte hayatımıza dahil olan bu türden gerçekliklerdir. Çünkü "modernliğin sonucunda ortaya çıkan yaşam tarzları bizi geleneksel toplumsal düzen türlerinin tamamından eşi görülmedik bir biçimde söküp çıkarmıştır" (Giddens, 2004, s.13-14). Geçmişe dair yaşanan tarihsel kırılmanın eşik değeri modernleşmededir. Fakat onun şiddetlenmiş (postmodern) hâli 'geçmişi hükümsüzleştirdiği' için tartışmanın odak noktasını daha radikal boyutlara (Beck, 2011) taşımış durumdadır. Bu açıdan 'ölüm, ölümsüzlük ve ölüm korkusu' bağlamında tarihsel süreçte anlamı büyük olan soyağacının; geleneksel, modern ve postmodern bağlamdaki hayata dair stratejik dönüşümlerini kavrayabilmek önemlidir. Bu açıdan yaşananlar, ölümün imgeselliği ve korkusuna dair alt metinler barındıran nitelikte dışavurumlar hükmündeydi. Bu nedenle çalışmanın bundan sonraki kısmı, yaşananları tarihsel temelli dönüşümler üzerinden anlamlandırma çabasında olacaktır. Bir bakıma gündelik bir olay olarak görünürlük kazanan soyağacı gündemi, taşıdığı tarihsel anlam açısından detaylandırılabilmiş olacaktır. 


\subsection{Geleneksel (Premodern) Toplumlar ve Bir "Ölümsüzlük Stratejisi" Olarak Sunduğu "Yaderk Stratejiler": "Ölümün Evcilliğinden" “Ölümsüzlüğün Vahşiliğine"}

İnsanlık tarihi dikkate alındığında, hayata dair ontolojik içerimleri açısından kültürel anlamda sunulan en belirgin strateji türü -Bauman'ın ifade ettiği gibi- daha çok geleneksel toplumlarda karşımıza çıkan 'yaderk (heteronomous) strateji' olmaktadır. Bu hayat stratejisi gelip geçici olan dünyayı sonsuzluğun içinde bir kesit haline getirmektedir. İnsana dünyada geçirdiği zamanı, 'sonsuz hayata dahil olan geçicilik' (bir yolculuktaki bir gecelik han konaklaması) misalinde sunmaktadır. 'Yaderk stratejilerde' asıl olan nokta; geçici olan hayatın sonunda, geçici olmayan bir hayat beklentisinin bireyleri karşıladığıdır. Buradaki yaşanan mutluluğun bedeli öteki hayattaki sonsuz ızdırap olabileceği gibi, yaşanan acının da bedeli sonsuz mutluluk olabilir. Bu yüzden geleneksel evrede bireyin yapması gereken şey kendisine verilen hükümlere sorgulamaksızın uymasıdır. Nitekim 'yaderk stratejiler' sorgulanmak istese de genelde sorgulanabilmesinin ya da sınanabilmesinin mümkün olmadığı aşkın bir strateji niteliğindedir. Burada anlamak önemli değil; önemli olan uymaktır (Bauman, 2012a, s.42).

Acı ilacın acısını alır bu strateji: Ölüm, ölen kişinin kabahati değildir, tıpkı doğumun onun erdemi olmadığı gibi. Kişi ne başlangıç ne de son karşısında kişisel sorumluluk taşımaz. Bu yüzden de bunları ihmal etti diye kendisine eziyet etmesi gerekmez... Yaderk çözüm, tanımı gereği bütün testlere ve deneylere kapalı olduğu için, yanlış ya da yanıltıcı olduğunun kanıtlanması mümkün değildir. Bu yüzden de verdiği emirler onu daha yakından inceleme yönündeki her türlü girişimin gözünü baştan korkutur. İleride duyulabilecek gönül bulandırıcı şüpheleri savuşturur ve insanı boş şeylere güvenmiş olmanın getirebileceği suçluluk duygusundan muaf tutar (Bauman, 2012a, s.4243).

Geleneksel (premodern) evredeki bu gerçeklik, ölümün kültürel anlamına dayalı olarak onun “evcilleştirilmesini” beraberinde getirmekteydi. Dünyanın her yerindeki tüm geleneksel açıklamalarda 
ölüm türleri aynı anlamdaydı. Çünkü tüm bu kültürlerde ölüm teması çok daha büyük bir düzenle ilişkilendirilmiş 'insani arzu' niteliğine sahiptir. Tüm kültürler ölümü insan ömrünü aşkın bağlamda açıklamışlardır (Spellman, 2017, s.16-18). Bu evrede yaşam tekdüzeydi ve bozulması da en nihayetinde tanrı vergisiydi. Tanrı vergisi olan şeyden kaçınılması ya da onun bir yazgı olarak değiştirilebilmesi mümkün değildi. Hatta tanrısal bir tasarruf olan bu 'kaçınılmaz sonun' ne zaman ve ne şekilde olacağı çok dert edilmez bir şeydi. Çünkü bu yazgıya karşı çıkabilmenin imkansızlığı onu hiçbir fani eylemselliğe açık hale getirmemekteydi. $\mathrm{Bu}$ durum gerçekliği insani açıdan uysallaştırıyor ve sonucunda 'ölümü evcilleştirmiş' oluyordu.

Hepsi sessizce (kelime yazar tarafından vurgulanmıştır) ölümü kabul ediyordu. Hesaplaşma anını geciktirmedikleri gibi, aksine yavaş yavaş onun için hazırlanıyorlardı... Sanki sadece ev değiştirmeleri gerekiyormuş gibi, bir tür dinginlikle tükeniyorlardı... Yüzyıllar ve bin yıllar boyunca böyle ölünüyor. Değişmenin tabii olduğu dünyada, ölüm karşısındaki geleneksel tavır, bir durgunluk ve süreklilik abidesi olarak ortaya çıkıyor. Ölümün bildik, yakın ve yumuşatılmış, önemsiz olduğu eski tavır, ölümün adını bile söylemeye cesaret edemeyeceğimiz kadar korku yarattığı bizim çağımızın6 tavrıyla fazlasıyla ters düşüyor. Bu nedenle burada, bu bildik ölümü ehlileştirilmiş (evcil) ölüm olarak adlandıracağım. Ölümün daha önceden vahşi olduğunu söylemek istemiyorum, çünkü ölüm vahşi olmayı bırakmıştı. Tam tersine ölümün bugün (modern evrede) vahşi hale geldiğini söylemek istiyorum (Aries, 2015, s.37-38).

Nitekim ölümün geleneksel toplumlarda böylesi bir evcilleşme yaşamasının bir başka anlamı 'ölümsüzlüğün vahşileşiyor' olmasındandı. Bu nedenle 'ölümsüzlük' bireye özgü bir gerçeklik olmadığg için, onlar tarafindan kovalanan ya da arzu edilen bir şey de olmamaktaydı. Çünkü "ölüme dair uhrevi

${ }^{6}$ Aries burada "bizim çağımızın" derken "modern evreyi" kastetmektedir.

$\mathrm{SAD} / \mathrm{JSR}$

Cilt / Volume 22 Sayı / Number 2 
açıklamalar onu insanların zihnine hep sabit bir şekilde işlerdi" (Hauzinga, 1997, s.198). Bu açıdan geçici olan hayatın nasıl kalıcı hale getirileceğinin bilgisi çok önemlidir. Sonlu hayatın sonsuzluk köprülerinin nasıl inşa edildiği çok önemli konulardır. İnsani kültür ölümlü hayatla ölümsüz hayatı birbirine bağlayan köprüleri mantığın tavsiyelerine uyarak yapmamaktadır. Hatta onlara rağmen bunu inşa etmektedir. Kültür, bireye içinde bulunduğu hayata dair istikrarlı ve kalıcı olanı vaat eder. Ölümden sonraki hayat da onun bu türden başarısıdır (Bauman, 2011, s.289-300). Bunun getirisi, 'yaderk stratejilerin' hayata dair kalıcı bir istikrar anlatısına dönüşebilmesi olmaktaydı. Ayrıca ölümün bu türden açıklanıyor olması, geleneksel bireyin gündelik hayat kurgusunu kendini aşkın gerçeklere ve doğal olarak da diğerlerine bağlayan bir yapıya erişmesini mümkün hale getirmekteydi. Çünkü böylesi bir hayatın geçiciliği, bireyleri geçici olmayan ölümsüzlük temalarındaki ilişkilere açık hale getirmekteydi. Bu açıdan 'yaderk stratejiler' bir bakıma içerisinde ölümsüzlük stratejilerini barındırmaktaydı ve ölümsüz olabilmek için dünyadan gidişi insansı bir gereklilik haline getirmekteydi. Bunu da geçmişle ilişkiselliği mümkün kılan 'soyağaçları' gibisinden ortaya koyduğu göstergeler ve sembollerle gerçekleştirmekteydi. Çünkü 'soyağaçları' bireyi, bireyin hayatını aşkın zamanlara açık hale getirmekteydi. Bu nedenle birey, yaşamı boyunca elde etmek istediği ölümsüzlük stratejisi açısından atalarına saygı ve kutsallık esaslı bir bağl1lık göstermek zorundaydı. Bu bir zorunluluktu, çünkü terk ettiği dünyada isminin ve izlerinin benzer bir saygınlıkla devam etmesi için kendisinin de yaşamı boyunca benzer rolleri sürdürmesi gerekmekteydi. Bir bakıma geleneksel evredeki 'insanı insana bağlayan yaderkliklerin' verdiği tarihsellik ve gelenek biçimi, geleneksel bireylerin ölümsüzlüklerinin anlatımını yapan türden şeylerdi.

O zamana dek, Aries'in ünlü deyişiyle, ölüm "evcil"di; ama bütün günlük felaketleri, salgın hastalıkları, savaşları ve selleriyle dünya da genel anlamda aynı durumdaydı... Bütün bunlar insanın yazgısına özgüydü ve yazgıyı değiştirmek insanların işi değildi: Değiştirilemeyen şeyden pişmanlık duyulabilir ya da hayıflanılabilir, ama sonunda yine o şeyle birlikte yaşanması zorunludur (Bauman, 2012b, s.166). 
Zorunluluk burada bir bakıma insani olan hayatın zorunluluğuydu (Arendt, 2013). Öyle ki "insan yaşamın güzelliğine karşılık ölümü genel olarak katı, sevimsiz ama birçok kötülüğe karş1lık dost bir zorunluluk olarak duyumsar" (Feuerbach, 2015, s.182). "Bu fenomenleri iyi anlamak için, bu geleneksel yakınlığın, kolektif bir kader anlayışını içerdiğini hiç unutmamak lazım... Ölüme duyulan aşinalık, doğanın düzenini bir kabul ediş şekliydi... İnsan ölüm içinde, türünün en büyük yasalarından birine boyun eğiyordu ve ne bundan kaçmayı ne de bunu yüceltmeyi aklından geçiriyordu" (Aries, 2015, s.46). Bu yönüyle 'yaderk stratejilerin' aktif olduğu geleneksel (premodern) toplumlarda, bireylerin kendilerini kurguladığı tüm kodlar, kaynağını geçmişin inşa ettiği referanslardan almaktaydı. Tüm bu kodlar onları hiç sorgulamadıkları 'soy ilişkilerinin' merkezine çektiği içindir ki, bireyler 'soyun devamlılığına' (soyağacına) katkıda bulunarak kalıcılıklara ve ölümsüzlüklere açık hale gelmekteydi.

Soylar, aynı silsile içinde yer alan ve tekçizgili bir zincirle, bir ve aynı şecereye bağlanan insanlara dayanır... Bunlar, her üyenin paylaştığı ortak sembollere sahiptir, belli bazı pratikleri dayatırlar ve farklılaşmış birer birlik olarak benzerlerinden ayrışırlar... Bu türden toplumlarda, siyasal konumları belirleyen temel yasa esasen soykültürel yapıdır... Bireylerin toplum içindeki yerini belirlemeye ve ataya referansla nesebi teşkil etmeye yarayan soyzinciri grupları(dır) (Balandier, 2010, s.53-57).

Geleneksel toplumlarda 'bugün', ölümden sonraki hayata uhrevi şekillerde bağlanmaktaydı ve böyle olduğu için geçmişin/ataların/geleneklerin verdiği referansları sorgulamaksızın kabul etmek bir gerekliliğe dönüşmekteydi. $\mathrm{Bu}$ türden anlatılarda 'sorgulamak', bireylerin hayati hatalar yapmamaları adına engellenmekteydi. Nitekim fanilik, bireyin kendisini aşkın birlikteliklere bağlanınca, onun kişisel hayatına dair bir ölümsüzlük anlatısı haline gelebilmekteydi. Soyağaçları bu konuda önemli vaatler sunan bir araç niteliğindeydi. Çünkü atalar/geçmiş bireyin kendisine bir vaat olarak sunulan bir yaşam stratejisiydi. Burada hayatın anlamı ve ölümsüzlüğün gerekçesi/koşulu geçmişe bağl1lıkların ilan edilmesinden geçmekteydi. Bu kurgu soy ya da soyağacı merkezli anlatıları bireylerin gündelik hayatları için değerli hale 
getirmekteydi. Geçmişi bir ontolojik güvenlik söylemi görerek kutsayan, atalara tapınmayı bir erdem haline getiren toplumsal anlatı biçimleri, işte bu yüzden yaşayanlarla ölüleri (geçmişi/tarihi/geleneği) birbirine sıkı sıkıya bağlayan bir hale gelebilmekteydi. Premodern evrede ölüm, bireyleri yaşadıkları fani bir hayat bağlamında ölümsüzlüğe bağlayan bir aşama olduğu için 'evcilleşmiş' bir gerçekliğe dönüştürülmekteydi. Bunu en çok da soyağaçları gibisinden araçların gölgesinde başarabilmekteydi. Nitekim soyağaçları, bireylerin hayatına büyük anlamlar katan önemli bir araca dönüştürülmüştü. Daha ileri giderek; soyağaçları, bireylerin yaşadığı fani hayatı değerli/anlamlı kılan önemli bir referans değeri taşımaktaydı. Bu bakımdan soyağaçları yaşanan sonlu hayatın gölgesindeki önemli bir araçtı. Çünkü sonlu hayatlar yaşadığının bilincindeki dünyevi canlılar için bir ölümsüzlük vaadi niteliğindeydi. Modern evre ise bu tarihsel koşulları ve imkanları ortadan kaldıran ilk kırılma eşiği olarak onun kurgusal niteliğini aşındıran bir süreç oldu.

\subsection{Modern Toplumlardaki "Yaderk-Özerk Stratejiler" ve "Ölümün Vahşileşmesi”}

Modern evredeki dönüşümlerle birlikte, yaşama dair 'yaderk-özerk' (heteronomous-autonemous) stratejilerin yükseldiğine tanık olundu. Bu strateji, modernliğin ortaya çıkardığı hayat tarzı karşısında, premodern (geleneksel) evreye özgü 'yaderk stratejinin' verdiği garantilerin giderek çözülmesiyle yükselişe geçmişti. 'Yaderk-özerk' stratejide, önceki stratejinin eleştiri kabul etmeyen hükümlerine, yaratılış mitolojilerine ve vahyin tek seferlik inayetine başvurabilmek artık ikna edici olmaktan çıkmıştı. Çünkü böyle bir hayat modern bireylere atıl, tekdüze bir hayat tarzı gibi gelmekteydi ve buradan hareketle geçmişle arasına mesafe koymanın getirdiği bir değişimi hayatın merkezine çekmekteydi. Bunu yaparken de daha çok dünyadaki geleceğe dönük yollar ve vaatler sunan bir tarzda davranmaktaydı. Artık bu evrede miras alınan ya da öğrenilen kurallar (gelenek/geçmiş mukabilinden şeyler) ve araçlar yeterli olmaktan uzaklaşan kurallar haline gelmişlerdi. Vahyedilmiş bilgelik ve kendi seçimleriyle ilerleyen dünya arasındaki mesafe gitgide açıldı. Bu noktada bireylerin dünyevi olan (uhrevi olmayan) kendi eylemsellikleri üzerine kurulan hayat stratejileri artık daha makul bir davranış kategorisine bürünmekteydi (Bauman, 2012a, s.43). Çünkü 
tüm anlamlılık kategorileri dünyanın sınırları içine çekilen şeyler olmuştu. Öyle ki ölüm dahi uhrevi anlamından arınmış, giderek kişisel bir suça ve 'kurgulanan' modern hayat tarzının üzerinde bir bask1 aracına dönüşmekteydi. Ölümü uhrevi anlamalarının dışına çıkaran bu türden yeni koşullar, onu tamamen 'teknik' koşulların ürünü olan bir gerçekliğe indirgemekteydi (Aries, 2015). Modern evredeki 'tıbbileşen (teknikleşen) ölüm' biçimleri, bu nedenle giderek kişiselleşen sağlık ve beden algılarını geçmişle (atalarla) ilişki kurarak açıklayan geleneksel anlatı biçimlerinin dışına çıkarmaktaydı. Kellehear'ın aşağıdaki alıntısı modern evrenin ölüme bakışını özetleyen iyi bir örnek niteliğindedir.

Biyolojik olarak konuşacak olursak ölmek (uhrevi anlamının çok dışında) sadece birkaç değerli saniye ya da ender olarak birkaç dakika alır. Ölümün fiziksel süreciyse genellikle vücudun gerektiği gibi çalışmayan bir organında başlar ve vücudun her bir odasından çıkarken ışığı dikkatle kapatarak yayılır. Doku ve hücrelerin kapanması her şeyi pelteye, sonra gaza ve daha sonra da toza dönüştürür. Sonra "bizim" tozumuz geniş bir mikro parçacık kardeşliğine katılır (Kellehear, 2012, s.10).

Modern çağ 'dünyaya dair' inşa ettiği 'anlamlı gelecek projeleri' nedeniyle ucunda ibresi bulunan bir evreydi. $\mathrm{Bu}$ ibre onun, zamanı tamamen dünyanın sınırları içine çekebilen anlatılar inşa edebilme yeteneğinden kaynaklıydı. Bu ibrenin yönü, ortaya koyduğu 'proje vaatleri' nedeniyle, dünyadaki geleceği gösteren bir ok misaliydi. Onu böylesi bir tarife açık hale getiren şey sonunda (gelecekte) varılması anlamında vaat ettiği noktalar (hatta gelecekler) olmaktaydı. Bu yüzden modern evrenin bu dünyaya dair idealleri ya da devrimci anlatıları vardı. Bunlar geleneksel masallardan farklı anlatılardır. Çünkü dünyanın, ülkenin, kabilenin başlangıcına dair 'sıfır noktasını' neden-bilimsel mitlerden farklı şekillerde anlatmaktaydılar. Modern öncesi zamanlarda yapılmaya çalışılan şey, varlıkları daha çok doğumlarıyla (ve dahil olacakları soy zinciriyle) açıklamaktı ve böyle bir temelde 'yasallaştırmaktı'. Bu yüzden en önemli an doğumun olduğu zamandı ve diğer zamanlar değersiz görülmekteydi. Çünkü geleneksel bireyin doğumu onun bütün hayatını, 
soy zincirini ve hatta öldükten sonraki hayatının da niteliğini veren başlangıç anı olmaktaydı. Modern projelerde (milliyetçiliklerde ve ideolojilerde) durum böyle değildi. 'Bu üst anlatılar' daha çok geleneksel anlatı biçimlerinin ve de araçlarının 'yasallığını' iptal etmek ya da saçma olduklarını ilan etmek için söz konusuydular. Projenin adı da zaten bu yüzden 'modern' olmaktaydı. Böyle anlatılar başlangıçta 'yasal' projeler değillerdi. Ama her birinin gelecekle ilgili bir vaatleri vardı ve gelecekte bir yerde ya da bir günde vaat ettiği ideanın gerçekleşeceği vaadinde bulunmaktaydılar. Bu nedenle her biri bir gün yasal hale geleceklerini ifade etmekteydiler. Modern bireyden beklentileri de sadece bu dünyaya dair performansları olmaktaydı. Burada asıl olan şey, soy zincirine mukabil ölmek değil, projeye katkı sağlayan dünyevi performanslar olmaktadir.

Böyle üst-anlatılarla oluşturulan zaman hapsolup kalmaz, tersine hız kazanır. Bütün rekabet halindeki anlatılar kendilerini geleceğin henüz yazılmamış tarih kaydında test etmeye, kendilerini yarının başarıları arasında kanıtlamaya çağrılır. Doğum belgeleri ve özenle hazırlanmış soyağacı şemaları saçıp savurarak geçmişe bakmanın artık hiçbir anlamı yoktur. Bitiş çizgisi görüşü, varsayımı (mit değildir; çünkü çizgiye henüz ulaşılmamıştır, görüntüsü ne gerçektir ne de sahte, hâlâ kanıtlanması gerekmektedir) başlangıç mitlerinin yerini almıştır (Bauman, 2012b, s.200).

Modernitede çok fazla proje vardı ama hepsinde zaman şimdiyle sonrası (gelecek) arasında uzayıp gitmektedir. Bu anlatı biçimi aslında şimdiyi kendi başına değersiz gören ama geleceği mümkün kılması açısından değerli gören bir anlatıydı. Şimdiki zamanın değeri ancak bireyin kendi mutluluğunu erteleyerek geleceğe sağlanabilecek katkısında görülebilirdi. Bu açıdan modernite 'doğal yollarla' üstesinden gelinemeyen 'ölümlülüğü' kendi anlatı dünyasında 'yapısöküme uğratmıştır' ve onu dünyadaki kurgulanan geleceğe eklemleyerek üstesinden gelinebilecek bir hastalığa dönüştürmüştür. Fakat bunu yaparken 'ölümün vahşileşmesi' denilen gerçeklik ortaya çıkmaktaydı. Çünkü ideal bir zamanda (gelecekte) vaat edileni yaşamak için, tasarlanan geleceğe erişmek bireyin kendi kontrolündeydi ya da sorumluluğundaydı. 
Bu nedenle modernite vaatlerden uzaklaşmamayı bireyin eylemlerine bağladığı kadar, yaşamsal (bedensel) anlamdaki varoluşsal koşulları da -bir bakıma dünyada olmayı ve ölmemeyi- bireyin kendi omuzlarına yüklemekteydi. Tüm bunlar ölümü vahşileştirerek kişisel bir suç haline büründürmekteydi. Ölüm bu şekliyle uhrevi anlamından arındırılarak, kişisel sorumlulukların ve bireysel eylemlerin ürünü (ölümün tıbbileşmesi mukabilinde olduğu gibi) bir gerçekliğe indirgenmişti (Bauman, 2012b, s.200-201). Fakat burada seçilmemiş kader hâlâ bireyin 'anlamsı' olması muhtemel hayatını; millet, ideoloji ve aile gibi 'gerçeklikler' bağlamında iptal edip onu sonsuzluğa bağlayabilir bir kertedeydi. Bir bakıma ölümlü hayatı daha "hayali birliktelikler" üzerinden anlamlı hale getiriyordu. Fakat bu kez ortada soyağac1/soyzinciri benzerinden çok daha somut araçlar ve göstergeler yoktu. Buradaki araçlar Anderson'un (2017) da vurguladığı gibi daha çok 'hayali' nitelikteydi. Fakat bunun için bireylerin öncelikle mevcut durumu kabul etmesi şarttı ve bu nedenle modern bireyin yolu 'iradi bir yol' olmuş oluyordu. Bu açıdan totalitenin (ulus, milliyetçilik, ideoloji gibi) sürdürülebilirliği umarsız bir kaderin cilvesi olmaktan çıkmaktaydı ve bireylerin yapıp ettiklerinin (eylemlerinin) ürünü bir gerçekliğe dönüşmekteydi. Artık mesele ölümden sonraki ödüllendirme ya da cezalandırma şeklinde işletilmiyordu. Buradaki 'anlamlı aşkınlık' daha çok hedeflenen projelere uygun rasyonel (ussallaştırılmış) kurgular açısından doyurucu bir hayat üzerinde şekillenmekteydi (Bauman, 2012a, s.43-44).

Geleneksel (premodern) evredeki 'ölümsüzlük için ölmek bir zorunluluk' olduğundan, geleneksel bireyler için ölümün anlamı 'evcilleşmekteydi'. Ölüm bu evredeki haliyle bireylerin hayatını soyağacına dahil edebilen ve onları ölümsüzlük stratejisine her an eklemleyebilen araçlar niteliğinde olmaktaydı. Fakat modern evrede ölüm, vaat edilen zamanlar gelmediği sürece olmaması gereken bir gerçeklikti ve şimdiki zaman için ölümün anlamı 'vahşi' (istenmeyen) niteliklerdeydi. Çünkü modern projelerde vaat edilen mutluluğa kişilerin yakın zamanda erişebilmeleri pek olası değildir. Bu açıdan mutluluk ertelenerek yarın sahip olunabilecek bir dizgeye dönüşmüş olmaktaydı ve şimdi (bugün) gelecekteki vaat edilen zaman (ya da devrim) için lanetlenmiş olmaktaydı. Bu yüzden şimdiki zaman kendini dünyadaki geleceğe adamadığı 
sürece anlamsızlaşmaktaydı. Ölümün lanetlenme nedeni de bundan ötürüydü (Aries, 2015). Çünkü vaat edilen projelere erişmeksizin ölmek bireyi ancak 'meçhul asker' simgeselliğindeki gerçekliklere bağlar ki (Bauman, 2015, s.94), bunun da anlamı bireyin ölümünün onu soyağacı mukabilinden net göstergelere açık bir kalıcılığa kavuşturmayacağının anlatımıdır. Burada ölümsüzlük, ölümün bireysel olmasının aksine, kolektif bir ölümsüzlüktür ve bireyin mevcudiyetini (dünyevi varoluşunu/ismini) net/somut bir tarihselliğe (aşkınlığa/kalıcılığa) açık hale getirmektedir. Modernite bunu yaparken, bireylerin bu tür anlatıları ve vaatleri kabul etmeleri için onlara çok zorba davranmadi (Bauman, 2012b, s.200-202). 'Önceki premodern anlatıların (zorba tanrıların) aksine çok katı söylemler geliştirmemekteydi' (Bauman, 2014). 'Artık bireylerin gelenek olarak anladığ sadece tasarlanmış geleceğe hizmet edebilmek adına anlamlı bir kurgu biçimiydi.

Modernite ölümün yapısını sökerek onu bir çuval hoş olmayan ama iyi edilebilir hastalığa dönüştürdüyse, böylece bunu izleyen hastalıkla savaşma karmaşası içinde ölümlülük unutulabiliyorsa ve endişe yaratmıorsa... (bunun nedeni) görkemli, ama uzak ölümsüz mutluluktur... (Modernitede) Hem tarih hem de bireysel yaşam önlerindeki bir hedefe (geleceğe) doğru koşuyordu... Projeler yalnızca o âna değil, aynı zamanda geçmişe de yön (anlam) veriyorlardı (Bauman, 2012b, s.202).

Bir şeyi unutmamak gerekir ki modern evrede hâlâ işlemeye devam eden önemli iki totalite biçimi vardı: Bunlar 'millet' ve 'aileydi' (Bauman, 2015, s.291-292). Yarı yaderk yarı özerk olmaya neden olan karışım da buradan kaynaklanmaktaydı. Özellikle 'millet imgesi'; 'zorunlulukla seçimi', 'var olmakla yapmayı' (eylemeyi), 'ölümsüzlükle ölümlü hayatı', 'kalıcılık ile geçiciliği' birbirine tam olarak uydurmaktaydı. Bu haliyle geçicilik ve kalıcılık 'milliyetçilik söyleminde' iç içe geçmekteydi. Çünkü 'bireysel ölümlülüğün saçmalığı', bütün ölümlü hayatların katkıda bulunduğu 'milletin ölümsüzlüğü' sayesinde başa bela olmaktan uzaklaştırılmaktaydı. Bu türden 'ölümsüzlük' biçimi hâlâ ölümlü bir hayatı anlamlı hale getirmeye yardımc1 
olabilmekteydi (Bauman, 2015, s.295-296). Hatta bu ölümsüzleşme durumu, bireylerin kendi eylemlerine (yapıp ettiklerine) bir aşkınlık kisvesiyle bağımlı hale getirilmekteydi. Burada bireyden istenen şey, kendi hayatını milletin hayatta kalmasına ve refahına adaması olmaktaydı. 'Yaderk-özerk' strateji tam da bu gerçekliklerinden ötürü, bölgesel (ulus-devlet) temelli ve doğrudan ulaşılabilen cemaati (ve gelenekleri) eritip bölgeler üstü ve 'hayali (ulusal)' hale getirmişti. Böyle olması ise işlevini yitiren 'yaderk stratejinin' yerine 'yeni role' uygun bir stratejinin geçmesi gerekliliğinden kaynaklanmaktaydı. Çünkü daha geniş yığınlara hitap edebilecek bir 'hayali anlatı' biçimi modern evrede fazladan işlev üstlenebilecek durumdaydı. Burada artık yüz yüze ve kişisel deneyimlere ihtiyaç duyulmamaktaydı. Fakat bu ortaya çıkan durum da artık kalıcılık stratejilerinde soyağacı gibisinden önemli somutlukları bahşedebilen türde değildi.

Millet -yoluyla- ölümsüzlük; kahramanların ya da diğer sıra dışı, herkesten farklı ve herkesten yüce şahsiyetlerin değil sıradan halkın boyuna göre kesilmiş bir kumaştı. Bu ilacın etkili olabilmesi için cüretkarlık değil uyumluluk; standartları yıkmak değil itaat etmek; yeni yollar açmak değil sınırlara riayet etmek gerekiyordu... Aynı avantaj, modern yaderk-özerk stratejinin odak noktasındaki bir diğer totaliteye, aileye de ayrıcalık tanıyordu (Bauman, 2012a, s.45-46).

Modern evrede 'aile', bireysel ölümsüzlük ile kolektif ölümsüzlük arasındaki modern diyalektiği 'milletin' ortaya koyduğundan çok daha net bir biçimde sergiler. Fakat buradaki aile artık geleneklerden ve soyağacı zincirlerinden arınmış 'çekirdek' ailedir. Burada 'ölümlülük ve ölümsüzlük', ' yaratma ve yaratılma' yönleri en çok ailede karşı karşıya geliyordu. Modern evrede herkes bir ailede doğar ve aile yaratmaya çağrılmaktaydı. Modern bireylerin doğduğu ve yaratacağı aile 'çok uzun' bir akrabalık/yakınlık (millete/ulusa katkı) bağındaki noktalar olmaktaydı ve devamı için her bireyin katkısına ihtiyaç duyulmaktaydı. Ailedeki ölümlülerin yapıp ettikleriyle ortaya konulan ölümsüzlük tiyatrosu, herkesin izlemesi ve oyunda yer almasıyla sahneye konulur (Bauman, 2012a, s.45-47). Bu durum modernleşmenin gelişiyle birlikte, ailenin bireyin hayatındaki merkezi önemini herkes için geçerli olan bir hale getirmişti. 
Buradaki ölümsüzlük stratejisinin hayali tarzda işleyen hali bireylerin de ölüm sonrasındaki izlerini hayali tarzlara büründürmekteydi. Bu nedenle ölüm yerine dünyada kalış bu evrede giderek daha değerli olmaya başlamıştı. Bu noktada soyağacı kayıtları (her ne kadar aristoktratik özentisi olan bazı burjuvalar buna aykırı davranmaya çalışsalar da) bir toplumsal statü aracı olmaktan uzaklaşmaya başlamışlardı. Çünkü ne ortaklıklar ne de 'biz' (ya da toplum) artık bireyin algılayabileceği somutluklarda bir geçmişle ya da atalar kültüyle açıklanabilir araçlara sahipti. Atalar modern evrede bir ulusa geçmiş inşa edebilen kurgular olabilirdi ama şahıslar bağlamında belirsizlikler/meçhullükler inşa ederek bunları yapmaktaydı. Nitekim somut bir geçmiş ya da atalar bağlamındaki soyağaçları giderek anlamını yitirmekteydiler.

Yaderk-özerk strateji kişinin kendi ölümlülüğünün farkında olmasının getirebileceği yıkıcı etkileri, hayatın anlamını ölümsüz olduğu umulan kolektivitelere kaydırarak ve bireylerin ölümlü hayatlarını kolektif ölümsüzlük üretimi işine dahil ederek savuşturuyordu. Birey, yapısı gereği yaralanmaya açık ölüme-doğru-yaşamanın saçmalığıyla başa çıkmaya çalışmanın getirdiği şiddetli 1stıraptan korunmuş oluyordu. Onmaz biçimde kırılgan, emniyetsiz kişisel varoluşun ürkütücü hakikati, yadsınmasa da karartılmış; bunun neden olabileceği zarar ise telafi edici bir meşguliyetle, yani grubun emniyetiyle meşgul olmakla, ortadan kaldırılmış olmasa da sınırlandırılmış oluyordu. Kişinin öleceğinin farkında olmasının yarattı̆̆ı korkular, en azından kısmen kendisinden daha büyük totalitelerin varoluşsal emniyeti için duyulan kaygılara yönlendiriliyordu: ne kadar kısa ve kırılgan olursa olsun bireysel hayatın anlamı, ölümlü bireylerin tersine, gerçekten ölümü yenme gibi bir şansı olan bu totalitelerden çıkarılıyordu (Bauman, 2012a, s.47-48).

Tüm bu anlamlarıyla birlikte soyağaçları ya da şecere mukabilinden söylemler modern toplumlar için giderek anlamını yitiren şeyler oldular. Çünkü hayat gelecekte vaat edilen bir zaman dilimindeki ideallere adandığı için, dünyada vaat edilen zamana erişmek kaygısını taşıyan bir sürece dönüşmüştü. Bu yüzden bugünün ertelenmesine neden olan hayat stratejisi, 'şimdiyi' gelecekteki ideallerin (vaatlerin) bir parças1 
haline dönüştürmekteydi. Böyle bir hayatta ortaklıklar artık çok geniş yığınlara (ulus, millet gibi kavramlara) karş1lık geldikçe, böyle bir birliktelik daha çok 'hayali kurgular' üzerinden işlemekteydi. Hayali olan birliktelik eskisi gibi daha küçük parçaların üzerinden işletilen soyağaçlarını ortadan kaldırmakta ve hatta bu yönlü simgesellikleri farklı gerçeklikler vasıtasıyla işletilebilir hale getirmekteydi. Burada ölümsüz olmanın tek bir yolu olabilirdi ki tek yaderk gerçeklik etkinliğini orada ortaya koyabilirdi; o da ailenin devamlılığına yapılan biyolojik katkının ulusun/milletin devamlılığa katkı sağlamayı mümkün kılmasıydı. Fakat bu durum dahi bireysel bir yükümlülük olan 'ölümü evcilleştirmeye' yetmiyordu. Çünkü proje baştan dünyeviydi ve ölüm ötesi hayat için bireye bir vaatte bulunmuyordu. Artık yaşamak tüm bu nedenlerle ölmekten daha elzem bir gerçekliğe karşılık geliyordu. Çünkü vaat edilen zaman (projede vaat edilen son) gelmedikçe ölmemesi gereken bireyin ölümü zamansız bir ölüm olduğu için artık istenmeyen bir şeydi. Bu yüzden modern evrede ölüm 'savaşılması gereken' bir gerçekliğe dönüşerek, istenmeyen (vahşi) bir gerçeklik haline gelmişti. Artık 'hayali' bir nitelik kazanan 'geçmişin' soyağaçlarında karşılık bulmamasının anlamı da buradan kaynaklanmaktaydı.

Daha önceden tavsiye edilen şey artık yasaktır... Ölümün nasıl bir tabu haline geldiğini ve XX. yüzyılda temel yasak olarak nasıl cinselliğin yerini aldığını gösterdi... Toplum, cinsellik üzerindeki muhafazakar baskıları gevşettikçe, ölümle ilgili olayları da o kadar reddediyor... Ölüm karşısındaki modern tavır (bu yüzden), mutluluğu korumak amaciyla ölümün yasaklanması oldu (Aries, 2015, s.84-86).

Nitekim modern evrede geçmiş hâlâ kadimselliği ve anlamı olan bir geleneksellikti. Hatta tarih olarak büyük bir anlatı olma niteliğini -her ne kadar farklı şekillere büründürse de- devam ettirmekteydi. Fakat artık atalar, bir soyağacı çizgisinde aranan şahsiyetler olmaktan uzaklaşmışlardı. İçinde 'meçhullüğü' barındıran hayali şahsiyetlere dönüşmüş durumdaydılar. Bunun da en temeldeki nedeni hayatın dünyadaki bir zaman dilimine adanması beklentisindendi. 


\subsection{Postmodern Toplumlardaki "Özerk Stratejiler", "Ölümsüzlüğün Evcilleşmesi” ve Parodikleşen Soyağacı Gündemi}

İçinde bulunduğumuz geç modern (postmodern) evrede artık bireylere sunulan hayat stratejisi "yaderközerk” stratejinin ötesine geçerek tamamen ‘özerk’ hale gelmiştir. Ancak ‘özerk stratejinin’ etkin olduğu bu evrede ölümlülüğü aşmak şöyle dursun, önceki dönemde emniyetli olan ve yaderklik vaat eden kurumlar da (aile ve millet gibi) giderek çözülmektedirler. Giddens'ın vurguladığı gibi 'gelenek ötesi' (post traditional) hâle gelen bu evre, her türden geleneksel anlatının giderek aşındığı bir evre niteliğindedir (Giddens, 2004; 2010). 'Gelenekselliğin aşınması' süreci, bir bakıma gündelik hayata dair istikrar vaadinde bulunan her türden söylemin ya da pratiğin giderek işlevsizleşmesi anlamına gelmektedir. Bu bakımdan 'geç modern' evre, modern evrede ortaya çıkan ve istikrar vaadinde bulunan gelenekselliklerin aşınması anlamına gelmektedir. Bu yüzden postmodern evrede, modern hayata istikrar yükleyen anlatı biçimleri büyük oranda değersizleşerek ortadan kalkmaya yüz tutan şeyler oldular (Bauman, 2012a, s.48). Soyağacının modern evredeki aşınmasına benzer şekilde, ulus ve millet gibi geçmişle ilgili referanslar postmodern evrede işlevsizleşmeye başladılar. Nitekim soy kurgusu ya da ölümsüzlük stratejilerinin kadim anlamını yitirmesi bu sürecin önemli çıktılarındandır.

Postmodern evrede yaşananlar, modernitenin ‘eritici güçlerinin' yeniden dizayn edilmesiyle ortaya çıkan yeni bir eritme evresidir. Modern evrede bireylere seçenek veren, istikrar vaat eden ve onları sınırlayan bir ev (aile) vardı. Bunu bozmak çok mümkün değildi. Çünkü her şey karşısında hâlâ sonsuza kadar sürebilecek bir kalıcılıktaydı. Fakat 'gelenek ötesileşmenin' yaşandığı günümüzde (yani postmodern evrede) bireyin gönüllü olarak uyabileceği, güvenilir olarak addedebileceği kurallar ve örüntüler gittikçe artan bir hızda azalmaktadır. Artık referanslar, ayă̆ı yere basan istikrar söylemlerinin aksine evrenseldir. Bireylerin kendini kurma stratejisi de istikrarını yitiren anlatılar nedeniyle giderek belirsizleşmektedir. Yaşanan hızlı değişimler ve onların ortaya çıkardığı istikrarsızlıklar (kalıcılık ve geleneksellik vaat edememek) bu dünyanın genel niteliğidir. Bundan ötürü içinde yaşanılan 'postmodern evre' bireyselleştirilmiş ve 
özelleştirilmiş (dolayısıyla tamamen özerkleştirilmiş) bir modernitedir. Artık erimeye başlayan şeyler bireyleri birbirine bağlayan şeylerin kendisi olmaya başladı (Bauman, 2017, s.30-33). Bunun anlamı, bireyi daha geniş komünitelere bağlaması muhtemel araçların, özerkleşen gündelik hayat stratejileri karşısında işlevsizleşmesidir. Tüm bunlar yaşanırken, modernitede anlamlı bir enstrüman olan 'toplumun' da (hayali cemaatin/geçmiş kurgusunun) giderek bir araya getirici, ortak kader algıları (ya da ortaklıklar) inşa edebilme işlevi hızla ortadan kalkmaktadır (Bauman, 2016).

'Proje odaklı (devrime ya da anti emperyalist mücadeleye endeksli) modern dünyada' gündelik hayat, o duruma neden olan tarihe (geçmişe ve atalara) endeksli yaşanmazdı ama bugünü var eden geçmiş bilinci soyağacı niteliğindeki kadar somut olmasa da- vardı ve bugünü mümkün kılan şey hâlâ geçmişin kendisiydi. Fakat postmodern dünyada ise 'eşzamanlılık' (ya da âna endeksli olmak) anlamın inşacısı olarak tarihin yerini almıştır (Baudrillard, 2012; 2015; Lyotard, 2014; Deleuze ve Guattari, 2017). Önemli olan şimdi ve burada olandır. Postmodern dünyada (modern dünyadakinin aksine) gelecek şimdiye bağlıdır ama şimdi geçmişe bağlı değildir. Hayat artık kendi kendini var eden kararlılıkların ve istikrarlı anlatıların (ya da ibrelerin) iptal edilmesinden başka bir şey değildir. Bireylerin şimdiki ânı, kendi kişisel geleceklerinin geçmişidir ve istikrarsızlıklar üzerine kurgulandığı için er ya da geç boş ve anlamsız hale gelmektedir (Bauman, 2012b, s.207-208).

Postmodern evrede gelecek temalı yaşamlar artmasına rağmen, gelecek artık bir belirsizlik yumağı hâline gelmiştir (Bauman, 2017; Beck, 2011). "Gelecek dünyadan eminliğini yitiren (geç) modern insan bu dünyaya değil, kendisine (doğru) atıldı; (birey) dünyanın potansiyel manada ölümsüz olabileceğine inancından uzaklaşınca (artık) onun gerçek olduğundan bile emin olamazdı" (Arendt, 2013, s.453). Çünkü hayat içinde bulunulan kısa epizotlara bölündükçe istikrarsılaşma büyümekte ve bu yüzden gelecek, bireyler için belirsizlikten başka bir anlam taşımaz hâle gelmektedir (Sennett, 2011b; 2012). Sonuç olarak geleceğe inanan bireyler geçmişi de yitirdikleri için onların yapabileceği tek akılcı şey, içinde bulundukları 
âna sarılmak olmaktadır (Bourdieu, 1998). Postmodernitenin gelenek ötesi bireylerine göre her şey kalıcılığını ve istikrarını yitirdiği için, şu anda yapılanların ilerideki deneyimlenmeyen sonuçları üzerine kafa yormak gereksizleşmektedir. Bu nedenle bugünün merkezinde gelecek olsa da (Beck, 2011) her yapılan şey sadece içinde bulunulan ânı (kısa sürelilikleri) karşılamak için yapılmaktadır. Hal böyle olunca buradaki her davranış daha başlarken istikrarsızlık adına başlamaktadır (Bauman, 2017). Postmodern evrede "şimdiki zaman ne sunuyorsa, şimdi -stok tükenene kadar- sunuyordur... Öyleyse hiçbir şey sonsuza dek yapılamaz... (Artık) “Ölüm bizi ayırıncaya dek” kimse benim ortağım değildir" (Bauman, 2012b, s.208209). Hal böyle olunca da sembolik değeri olan göstergelere (soyağacı gibisinden araçlara) artık bir gereklilik ya da ihtiyaç bağlamında yaklaşabilmek mümkün değildir. Çünkü ibresi kırılmış hayatlarda bu türden göstergeler artık işe yaramamaktadır. Nitekim aşağıdaki örneklerde görüldüğü gibi, kendi soy kurgularındaki geçmişleriyle (bir bakıma atalarıyla) karşılaşan bilişim çağındaki postmodern bireylerin verdiği parodik tepkiler aslında bu koşulların ürünü çıktılar niteliğinde olmaktaydı. Çünkü kendilerinin internet ortamında karşılaştığı geçmiş (soyağaçları), onların kısa epizotlara bölünen ve geleneksel olanla bağını anlamsız hale getiren hayatları için herhangi bir anlam ifade edebilen gerçeklikler değildir. Hayatları gibi kesitsel olan ilişki türleri de uzun süreli birlikteliklere açık olmadığı için, saygı ya da sembolik değer yüklenen niteliklerde tepkiler vermemekteydiler. 


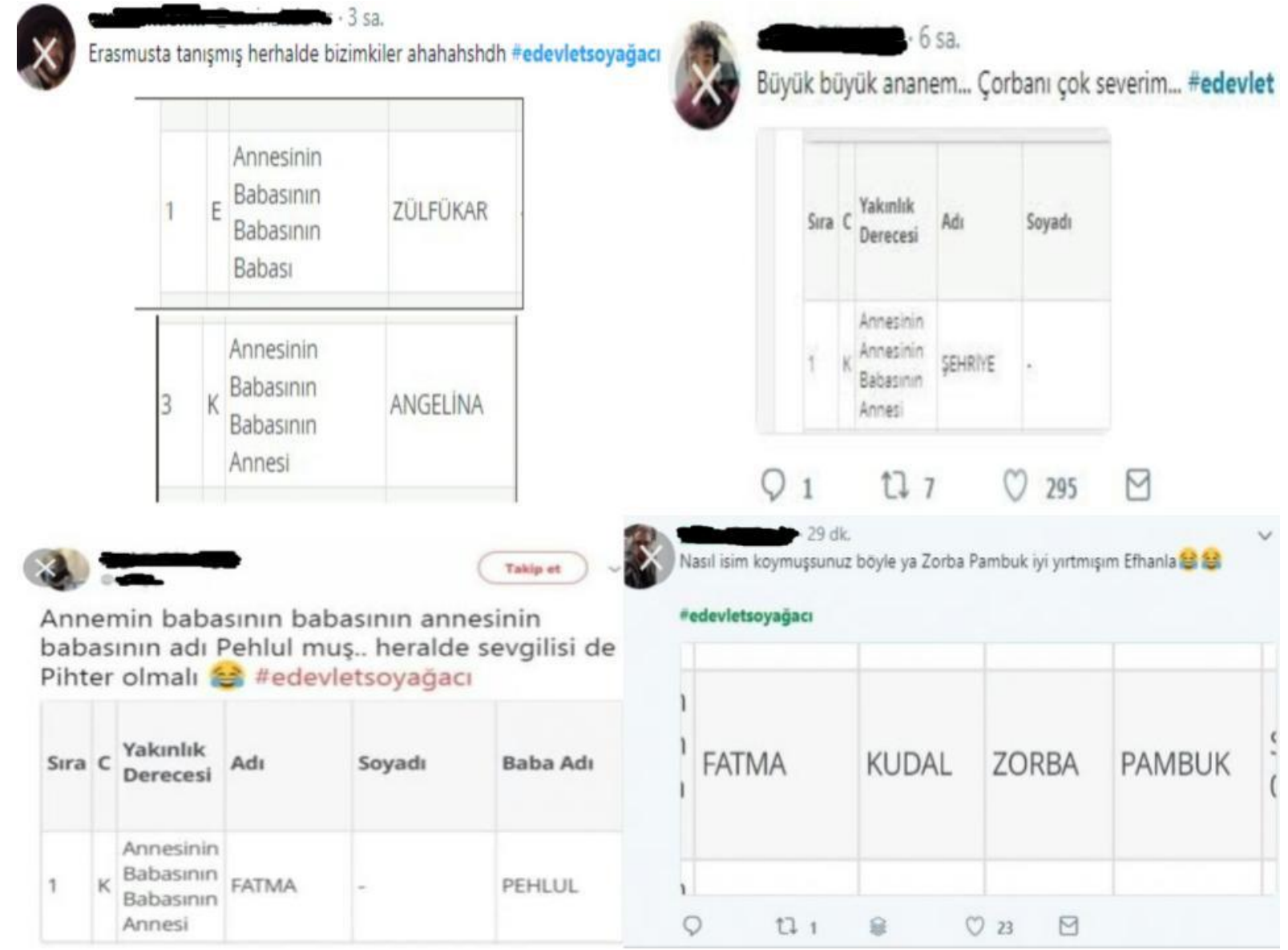

\section{Kolaj 1: Soyağacı Gündeminde Öne Çıkan Parodi Biçimi Karşılaşılan Atalara Saygı ve Bağlılık}

\section{Ortaya Koyan Şekillerde Değildi.}

Modernleşmenin hikâyesi, en açık ifadeyle bireyselleşmenin hikâyesidir. Fakat modernleşme şiddetlendikçe (postmodernleştikçe) bireyselleşmenin boyutu daha da radikal hale gelmiştir. Artık bireyselleşme, bireye doğuştan verilen bir şey değil; o bir süreç ve oluştur. Bu yüzden durmaksızın elde edilmesi gereken bir şeydir. Çünkü insanlar artık doğduğu pozisyonu ilelebet koruyamıyorlar. Bu yüzden bireyin kim ve ne olduğu bir soy kurgusunun ürünü olmaktan ötede artık kendi öz yönetiminin ürünüdür. Bu durum modernizmin başından beri vardı: Sınıf, kimlik, yurttaş da böyle bir şeydir. Fakat bu türden bireysellikler (kimlikler) bireyi başkalarına bağlayan cinstendi ama artık postmodern evrede sorunlar ve 
gündelik hayatı sürdürme biçimleri bireyleri bir araya getiren şekillerde değildir. Çünkü artık sorun olarak görülenler ve çözümleri tamamen bireysel hale gelmektedir. Böyle bir ortamda ise özgürleşmenin ad1, tercihin önemsiz ve yüksüz hâle gelmesi olmuştur. Bu nedenle özgürlük çaresizliğin ve bir yere varmayan gündelik hayat akışlarının kanıksanmasından başka bir şey değildir (Bauman, 2017, s.59-67). Kimliklerin parçalı hâle gelişi ve ortalığın bir kimlik mezarlığına (Bauman, 2012a, s.30-32) dönüşmesinin nedeni budur. Bireyi başkalarına bağlayan kimlik ve soy kurgularının anlamsızlaşması, içinde yaşanılan zamanlarda stratejik herhangi bir değerinin kalmamasıyla yakından alakalıdır. Nitekim soyağacı gündeminde kalıcı bir kimlik ya da geçmiş duyarlılı̆̆ı olmayan paylaşımlar bunun dışa vurumu niteliğindeydiler.

Modernliğin başlarında 'isnat' toplumundan 'başarı' toplumuna (yani insanların kimlikleri içerisinde ‘doğdukları' bir toplumdan, kimlik oluşumunun insanların görevi ve sorumluluğu olduğu bir topluma) geçişten bu yana, "kimlik" önemli bir mesele ve ilgi çekici bir iş olarak kalmasına rağmen artık başka yaşam donanımlarının kaderini paylaşıyor: Belirlenmiş bir yönden kesinlikle mahrum; artık arkasında katı ve yok edilmez izler bırakmayan kimliğin bundan böyle kolayca çözülmesi ve farklı şekillerdeki kalıplara girmeye uygun olması bekleniyor ve tercih ediliyor. Vaktiyle “yaşamın bütününe” dair bir proje olan kimlik, ânın bir özelliğine dönüşmüştür artık. Vaktiyle tasarlanan kimlik, artık "sonsuza dek devam etmek üzere inşa edilmez”, aksine sürekli olarak bir araya getirilmesi ve parçalara ayrılması gerekir (Bauman, 2013, s.25).

Aşağıdaki paylaşımlar da soy zinciriyle karşılaşan ama onun ne anlam ifade ettiğine dair hayatındaki izdüşümlerini görememiş bireylerin gündelik kurgularına özgü parodik tepki biçimleridir. Çünkü karşılaştıkları soy zincirindeki isimler ve mekanlar kendi postmodern hayatlarındaki isimler ve mekansal aidiyetler bağlamında bir anlam üretmediği için onlar da bu tarz imgeleri ânın akışı içinde bir bağlama kavuşturarak dişa vurmaktadırlar. Çünkü postmodern zamanlarda soy da soya dair mekansallıklar da kalıcılık içeren saygı ya da kutsallık içeren mitlerle karşılık bulamamaktadır. Bu tarz şeyler âna endeksli 
anlamlar üretmekten uzakta oldukları için bireylerce derinlik ve kalıcılık inşa edebilecek çıktılara dönüştürülememektedirler.

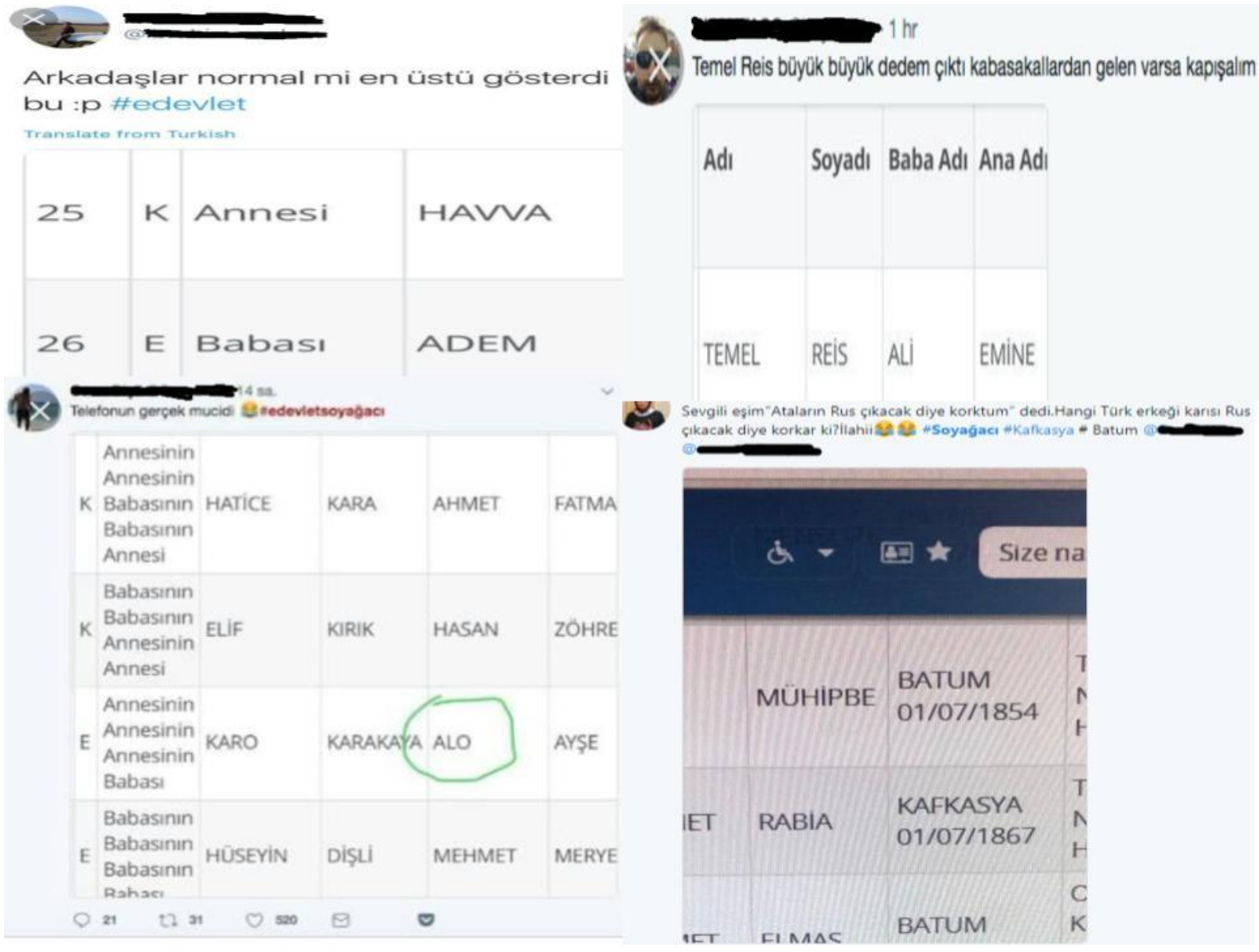

Kolaj 2: Kimlik Kişisel Bir Mesele Haline Gelince Komünal Değeri Olan Göstergeler (Soyağaçları)

\section{Gündelik Hayatlar İçin Anlamsız Hale Gelmektedir.}

Tüm bu gerekçelerle eşit ve birbirine herhangi bir üstünlügü olmayan anlardan oluşan postmodern evredeki özerk yaşamlarda 'yönlerden', 'projelerden' ve 'başarılardan' söz etmek artık anlamsızlaşmaktadır. Her an, en az öteki anlar kadar anlık ve geçici olduğu için, her bir an potansiyel olarak sonsuzluğa açılan bir kapıdır. Bu nedenle 'dünyevi olanla dünyevi olmayan', 'geçici ile kalıc1', 'ölümlü ile ölümsüz' arasındaki ayrım (Feuerbach'ın vurguladığının aksine) hemen hemen silinmiştir. $\mathrm{Bu}$ nedenle de gündelik hayat hem 
ölümlülüğün hem de ölümsüzlüğün süreklilik arz eden bir parçası haline gelmiş durumdadır. "Sonsuzluğun gelip geçici anlardan oluşan bir rastlantısal harekete dağılması sonucu artık hiçbir şey ölümlü de değildir" (Bauman, 2012b, s.209). Premodern hayat bireyler için 'ölümü evcilleştirmişti' ve bunu öte dünyayı vaat ederek yapmıştı. Modern hayat ise 'ölümü vahşileştirmişti' ve bunu da geleceği (ideal zamanları) vaat ederek yapmıştı. Ama şimdiki modernite (postmodernite) ‘ölümsüzlüğü yapısöküme uğratarak onu evcilleştirdi' ve bireylere vaat ettiği şey ise sadece şimdiki anlardan ibaret bir akış olmaktadır. Bu nedenle artık bireylerden kendilerini kurban etmeyi, yakmayı, sakınmayı isteyen zorba bir Tanr1 yoktur ortada (Bauman, 2012b, s. 207). Hatta gelecekteki ideallere erişmek için bugünü ertelemek isteyen seküler/modern anlatılar da artık söz konusu değildir. Bu nedenle postmodern evrede yaşananlar, sadece ânı karşılamaya çalışan 'radikal bireyselleşmelerin' ortaya çıkışı olmaktadır. Burada "insanlar... kendi tekil deneyimlerinin öznelliğine hapsolmuşlardır; aynı deneyim sayısız kere yinelenmiş olsa bile yine de tekil olmaktan kurtulamayacaklardır... sadece bir tek perspektiften sunmasına izin verildiğinde, müşterek dünyanın da sonu gelmiş demektir" (Arendt, 2013, s.102-103). Bunun anlamı geniş komünitelere bağlanma stratejileri vaat eden anlatıların ve araçların bireyin yaşamı adına değersizleşmesi olmaktadır. Sonucu da hem soy zinciri hem de millet gibisinden geçmiş kurgularının ve anlatıların giderek aşınmasıdır. Nitekim soyağacı gündemini parodik hale getiren trajikomik içerik, ölümün eski tarz görünürlügü ve anlamını yitirmesine neden olan 'ölümsüzlüğün evcilleşmesi' sürecinin çıktıları niteliğindeydi.

Gelip geçicilik ve kısa ömürlülügün günlük uygulamaya yeniden zorla sokulması, yüceltilmesi ve törenlerle kutlanmasıyla birlikte, hayatta kalma stratejisi tam bir döngü oluşturmuştur. Şimdi yıkılan ölümlülük değil, ölümsüzlüktür; ama öyle bir biçimde yıkılır ki, kalıcılığın gelip geçici olaylar dizisinden başka bir şey olmadığı, zamanın sonucu olmayan bölümlerin art arda gelmesinden başka bir şey olmadığı, ölümsüzlüğün ölümlü varlıkların birinin gidip birinin gelmesinden başka bir şey olmadığı açığa çıkarılır. Yıkılmasıyla birlikte ölümsüzlük tek sırrı olan 
ölümlülüğü açığa vurur. Ölümlülüğün yıkılmasına gerek yoktur. Yaşanması gerekir... Artık her şey insanın elindedir. Ama "her şey"in anlamı beklenen anlam değildir (Bauman, 2012b, s.233).

Modernite ortaya çıkarken ölümü aşkın (ve yaderk) anlamından mahrum bıraktığı için onu 'yapısöküme uğratmıştı'. Postmodern evredeyse 'ölümsüzlük evcilleştirildikçe', ölümün komünal anlamı (doğal olarak ortak kader algıları) giderek aşınmaya başladı. 'Özerk olan bu stratejide’ cemaat (birliktelikler) artık Tanrıyı oynayamayacak kadar zayıf durumdadır. Artık ortaklıkların kendisi yaralanmaya açık olunca, ölümsüz (bireyleri aşkın) diye kimseyi ikna etmesi mümkün olmamaktadır. Bu nedenle ölüm önceki anlamından çok uzaklaştı ve bugünlerde sadece bireysel hayatın sonu ve kendisini hiçbir geçmiş kurgusuna eklemlemeyen gidiş/ayrılış/veda hükmünde bir gerçekliğe karşılık gelmeye başladı. Çünkü fanilik ve sonsuzluk arasında kurulan köprüler (soyağaçları, uhrevi söylemler ya da hayali kurgular) işlemez olduğu için birey kendi varoluşsal emniyetsizliğiyle baş başa kalmıştır. Bu yüzden kendisinden ilgili sorunu her defasında yalnız başına ve hiçbir komüniteye bağlanmaksızın çözmesi istenmektedir. Artık parçalar bütünden büyük görünüyor ve bu yüzden ortaklıklardan medet umulamıor. Bu evrede totaliteler de bireylerin hayatları gibi ölümlü görünmektedirler. Çünkü gelecek adına hiçbir güven telkin etmemektedirler ve bu nedenle bireylere sonsuzluk hissi vermekten çok uzaktadırlar. Tüm bu yaşananlar bireyleri, kaçınılması mümkün olmayan yok oluş korkularıyla baş başa bırakmaktadır. Bu durumdan kurtulmak sadece bireylere ait bir yüke dönüşmüş durumdadır (Bauman, 2012a, s.48-51). Böyle bir hayatta hiçbir komünite etkinliğini koruyamadığı gibi, soyağacı ya da şecere mukabilinden göstergeler de geçmiş, atalar ya da gelenek olarak hiçbir anlam ifade edememektedir. Çünkü bireylerin kendisini merkeze koyduğu kısa epizotların ürünü hayatlar, onların hiçbir kalıcılık stratejisine bağlanmasını mümkün kılmamaktadır.

$\mathrm{Bu}$ nedenle aşağıdaki kolajda sunulan örneklerde olduğu gibi, hayatını kesitsel yaşayan postmodern bireylerin soy kurgularında karşılaştığı uzun erimli zamansallıklar, onlar için anlamsız şeyler haline gelmekteydi. Fakat bu durum aynı zamanda onların kendi hayatlarında böylesi gerçekliklere ne derecede 
yabancılaştığının da anlatısı niteliğindeki örneklerdir. Bireylerinin bu türden verdiği parodik tepkiler, onların anlamlı bir bütünlüğün parçası olma halini ne kadar değersiz gördüklerinin dışa vurumudur. Çünkü yaşadıkları hayata dair geçmiş hükümsüz bir gerçekliğe dönüşünce, 'ataların' (geçmişin) ya da 'soyağaçlarının' kendilerine sunacağı kalıcı bir anlatı biçimi olma ihtimali ortadan kalkmaktadır. Bu nedenle kendilerine geçmişlerini izah eden soy kurgularına bakanlar, onlardan yaşadıkları hayatlara dair anlamlar ya da duygusal yüklenimler üretememişlerdir. Bu yüzden de gördükleri manzara, kendilerine son derece anlamsızlaşan örneklere dönüşmekteydi. Bu açıdan büyük büyük 'Ahmet Dedenin' annesi büyük büyük 'Elveda Nine', torunu için kendi gündelik ilişkilerindeki kısa süreli koşullar adına ona "neden sürekli elveda edip durduğunu" anlatan sadece parodik bir göstergeye dönüşebilmekteydi. Fakat paylaşım sahibinin "sürekli elveda edip gitmesi" aslında onun kalıcı şeylere bağlanmaktan ne kadar uzakta bir hayat yaşadığının anlatısı niteliğindedir. Çünkü kalıcı bir hayat ancak terk etmeksizin yaşanabilecek bağlanmalar üzerine inşa edilebilir bir durumdur. Bu bakımdan postmodern koşullara özgü olarak onun her defasında 'ettiği elveda', neden istikrarsız bir hayat yaşadığının ve dolayısıyla da neden büyük komünitelere bağlanmayı anlamsız gördügünün dışa vurumudur. Bu nedenle böylesi bir paylaşım, 'geçmiştekilerin' postmodern zamanlarda yaşayan torunlarının hayatına dair neden bir kalıcı anlatıya dönüşemiyor olduklarının ispatı olmaktadır. Bilakis belirgin bir anlatıya dönüşememe halinden ötürü de sadece bir 'gösterge' değeri kazanarak sosyal medya ortamına aktarılabilen parodik nesnelere dönüşmüş olmaktaydılar. Buradaki manzara artık 'ataların' zamanları aşkın kalıcı bir anlatı olmaktan ziyade, nasıl tüketim göstergesine dönüşebilir olduklarının anlatımı gibidir. Bu nedenle onlar da tıpkı diğer her şey gibi göründüler ve kısa bir süre sonra yitip gittiler. Benzer şeyleri bir rastlantısallığın ürünü olan bir kombinasyon niteliğindeki büyük büyük 'Fatma, Ayşe ve Hayriye Nineler' için de 'Medine Nine ve Tevrat Dedeler' için de söylemek mümkündür. Kesitsel yaşama özgü niteliklerde ortaya çıkan bu durumun asıl belirleyicisi olan şey, postmodern hayatın belirsizliklerden kaynaklı anlamsızlık halinin kalıcılık kazanıyor olmasıdır. Bu da hayata büyük bir istikrarsızlık halini aşılamaktadır. 
Nitekim "soyunda Meryem sevdasını" görüp de benzer yönlü tepkiler vermek de aynı türden çıktılardır. Bir soy kurgusu eğer içerisinde hayata dair bir anlam taşıyabilir hale gelirse, bunun en önemli nedenlerinden birisi geçmişe bağlanmayı mümkün kılabilmesidir. Çünkü geçmişe bağlanma hali, bireylerin dünyadaki hayatlarına dair kalıcılık ve istikrar kaynağı sunabilen araçlar edinmelerini mümkün kılmaktadır. Geçmişe bağlanmanın anlamlı bir gerçeklik olduğunu anlatabilen en belirgin noktalardan birisi, onun bireylerin bugünlerine ne derecede etkisinin olduğuyla anlaşılabilmektedir. Nitekim bunun en temeldeki göstergelerinden birisi de soy kurgusundaki kuşakların benzer isimlerle bir bütünlüğün devamıymışçasına istikrarlı bir görünürlük kazanmalarından geçmektedir. Bu nedenle 'Meryem Nineden' sonra bir başka 'Meryem Nine' ve yine bir başka 'Meryem Nine'nin olması, geleneksel toplumlardaki bireylerin nasıl ölümlü hayatı aşkın stratejilerle birbirine bağlanmış olduklarını göstermektedir. Fakat postmodern zamanlarda hayatlar kısa epizotlara bölünürken bu bütünlügün parçası olma hali de ortadan kalkmaktadır. Nitekim hal böyle olunca da isimler, geçmişteki sürekliliğin devamı isimler olmaktan sıyrıldılar ve zamanın ruhuna özgü olarak güncelliğin ya da koşullara özgü popülerliklerin ürünü oldular. $\mathrm{Bu}$ nedenle 'Meryem Ninelerinin' isimleriyle karşılaşan postmodern zamanların torunu' yaşadığı böylesi koşullara dair yabancılaşmasını, kendi kesitsel kurgularından biçimlenen hayatında anlamlı bir yere oturtamayınca o da diğerleri gibi parodik çıktılarla bunu dışa vurmaktaydı. Aslında onun karşısında farklı kuşaklardan olsa bile birbirine sıkıcı bağlanmış bir geleneksellik vardı ve postmodern torunun anlamadığı şey de onların bu türden stratejilerle ölümlü hayatı aşkın bir stratejinin parçası olma çabasında olduklarıydı. 


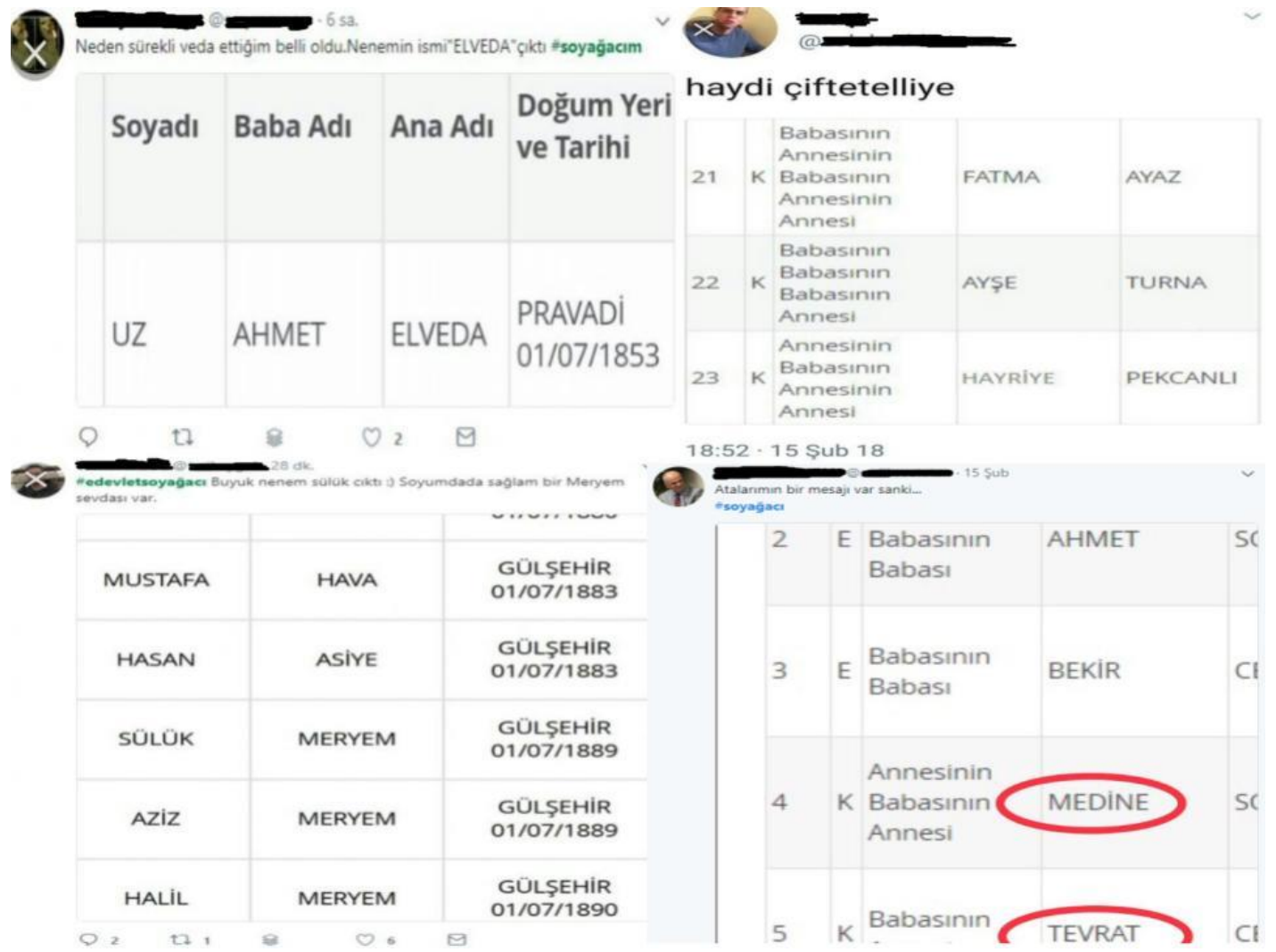

\section{Kolaj 3: Soyağacı Parodisi Kısa Epizotlara Bölünen Hayatların Dışa Vurumu Niteliğindeydiler}

Geç modern (ya da postmodern) bireyler bir bakıma gönüllü yalnızlıklar hatta "kitlesel yalnızlık fenomeni" (Arendt, 2013, s.105) yaşamaktadırlar. Fakat bu durum onların bireysel memnuniyetlerinden uzun sürecek herhangi bir şeyden nefret ettikleri anlamına gelmemektedir. Onların böylesi çabalarını bu yönde inandırıcı kılacak hiçbir uzun soluklu durum yoktur. Çünkü güvenli sığınaklar bir bir işlevini yitirmiş durumdadır. Önce dindarlık, sonra vatanseverlik ve aile babalığı kullanılmaz oldu (Bauman, 2012a; 49-50). Bu durum 'gelenek ötesi bireylerin' geçmişe, milliyetçi söyleme ya da soyağaçlarına neden ilgisiz olduklarını anlatan temel noktalardan birisidir. Fakat bu durumun bir anlamı da bireylerin yaşadığı hayatlara kadimsel anlamlar yükleyen algıların körelmesiyle de alakalıdır. Nitekim Türkiye'deki soyağacı hizmetinin başlangıçta büyük bir ilgiyle karşılanması; 'gelenek ötesileşerek' geçmişi yitirmiş bireyler için, bir kalıcılık ve kadimsellik göstergesine erişme vaadi sunması ihtimaliyle (hatta ümidiyle) yakından alakalıydı. Bu açıdan kitleleri 
itkisel olarak harekete geçiren ve interneti kilitlemeye neden olan asıl etken de burada gizlenmekteydi. Nitekim gündemin temelde parodik bir görünürlük kazanması, ilk etapta 'sosyal medya' gerçekliğinin ürünü olarak algılanabilir. Fakat kutsallar ve çok değerli olan toplumsal karakterler adına (örneğin Atatürk'ün soy zincirine verilen tepkiler gibi) henüz kitlesel bir parodi üretmeyen sosyal medya gerçekliği, e-devlet hizmetindeki karşılaşılan kişisel soyağaçlarında benzer bağlamda çıktılar üretmemekteydi. Soyağaçları tarihsel misyonlarına uygun şekillerde algılanmış olsalardı parodikleşen şekillerde kamusallaşma ihtimalleri ortadan kalkabilirdi. Nitekim tarihsel koşullara özgü beklentilerin dışındaki parodik paylaşım tipleri bu nedenle postmodern kırılmanın anlatıcısı niteliğindeydiler. Çünkü "başlatması kadar bitirilmesi, kurması kadar yıkması kolay olan ailenin ve bağlarının, onu meydana getirenlerden daha uzun süreceğine güvenilmiyor artık" (Bauman, 2012a, s.50). Hal böyle olunca soyağaçları, geleneksel evredekine benzer şekillerde, bireylerin ömürlerini aşabilecek niteliklerdeki etkiyi üretmekten uzakta göstergeler niteliğinde oldular. Çünkü ortada postmodern koşullara özgü yaşam tarzını benimsemiş postmodern hayatlar söz konusuydu. 


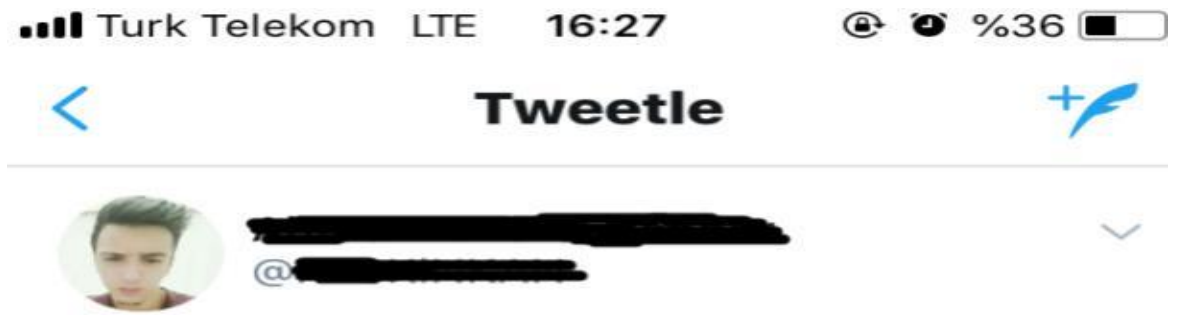

\section{Bu sey değil mi ya dunyanin en guzel soy ağacı} \#edevletsoyağacı

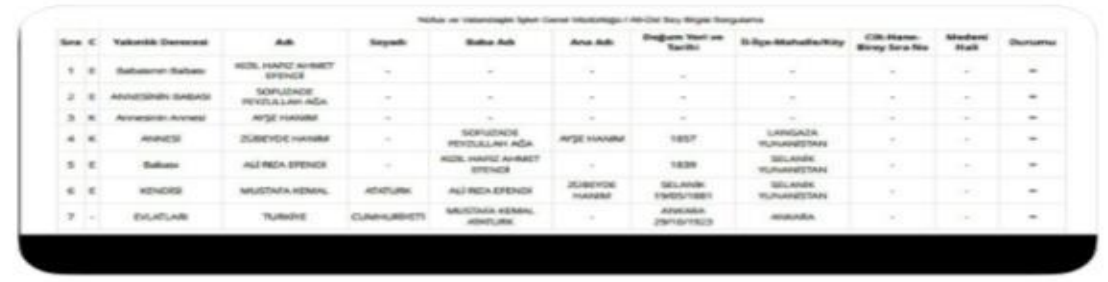

$16.02 .201820: 42$

33 Retweet 197 Beğeni

Resim 2: Atatürk'ün Soyağacına Verilen Tepkiye Dair Örnek Bir Paylaşım 


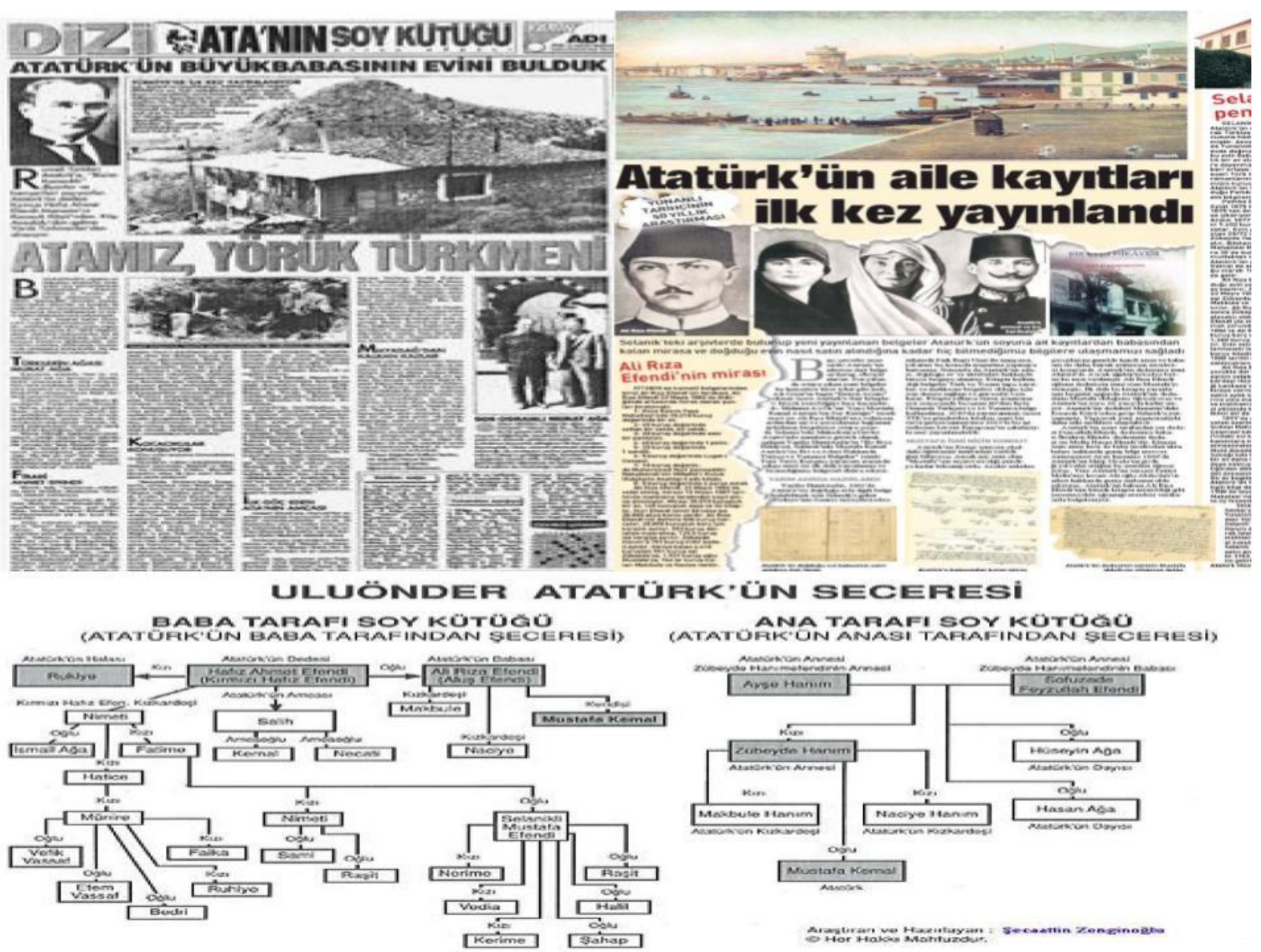

Kolaj 4: Atatürk'ün Soyağacının Medyadaki Görünürlüğüne Dair Birkaç Örnek

Postmodern evrede yaşananlar, savaş alanlarında sadece tüketimsel tatmin biçimlerinin peşinde koşmayı motive eden yalnız egoların kaldığını gösteren cinstendir (Bauman, 1999). Nitekim burada 'özerk' olan şey, kendini merkeze koymak anlamındadır. Bu nedenle geç modern evrede artık toplumsal ortaklıklar şeklindeki bağlarla (yaderkliklerle) kalıcılıklar ya da ölümsüzlükler inşa etmek mümkün değildir (Bauman, 2016). Yaşananlar bireylerin hayatında yapısal emniyetsizlikler üretmekte ve gündelik hayat sadece bireysel tavır alma biçimleriyle şekillenmektedir. Artık ortaya çıkan yeni ölümsüzlük çabası, tek seferlik bireysel edimlerin (istikrarsızlıkların) peşinden koşmayı merkeze koymaktadır. Postmodern bireyler böyle davranmaktadır, çünkü ölümün kaçınılmazlığını bir şekilde hayatlarından çıkarmak istemektedirler. Beden 
merkezli ve tüketim çığırtkanı yaşam politikalarının giderek yükselmesinin nedeni de buradan kaynaklanmaktadır. Bu yüzden içinde bulunulan zaman dilimlerinde 'kilo almak' mukabilinden bedensel dertler, en önemli dertler grubunda olmaktadır. Burada yapılan şey bastırılması artık mümkün olmayan ‘büyük korkuyu’ daha küçük parçalara bölerek baş edilebilir hale getirmek çabasıdır. Bedene odaklanma biçiminin yeni tarz görünürlüğü olan şişmanlık ve kilo şeklinde açığa çıkan problemler sadece kafay1 meşgul eden türde kaygılardır. Temelde yaşanan şey ise varoluşsal anlamdaki önemli kaygı faktörü olan 'bedenin ölümlü olduğu' gerçeğini bastırmaya çalışmanın kendisidir. Çünkü yaşanan korku temelde ölümün korkusudur. Görünenler ise onun parçalanıp dört bir yana dağılmış hali olmaktadır (Bauman, 2012a, s.50-55). Ortada görünen şey Baudrillard'ın tabiriyle söylersek (2012) "cümbüş misali hayatın" var olmasıdır. Böylesi bir hayatta her şeyin altından çıkan parodi temelde bu türden bastırma kültürünün sadece gündelik görünürlügüdür. Nitekim soyağaçlarıyla karşılaşanlar, bir bakıma insani hayata içkin geleneksel ölümsüzlük stratejisiyle karşılaştıkları kadar, onu mümkün kılan insani hayatın ölümlü haliyle de karşılaşmış oluyorlardı. Bu nedenle soyağaçlarının görünürlüğü, bireylere ölümlü bir hayatın varlığını hatırlatır nitelikteki örneklerdir. Atalara saygının bir nedeni de içerisinde insani ölüme saygıyı barındırmasından ötürüdür. Fakat kesitsel yaşam içindeki ölüm korkusunu bastırma hali, ölümün görünürlügünü de bastırmayı gerektirmektedir. Çünkü ölümsüzlük postmodern zamanlarda yapısöküme uğratılırken ölüm de giderek uhrevi anlamından sıyrılmış olmaktadır. Bu nedenle her şeyi cümbüşe dönüştüren postmodern bireyler, soyağaçlarında karşılaştıkları ölmüşlerini (atalarını) ve de insani ölüm şeklini bir parodik duruma karşıllı getirmek durumunda kalmaktaydılar. Çünkü ölümün bu türden görünürlüğü doğal haliyle kaldığında gündelik hayata içkin ölüm korkusunu bastıran cümbüş durumunun bozulma ihtimali söz konusuydu. Nitekim aşağıdaki paylaşımlar da ölüm imgesiyle karşılaşan postmodern bireylerin, ölüme dair gerçekliği baskılamak adına ürettikleri cümbüşe eşlik eden türden parodikleştirmenin örnekleridir. 


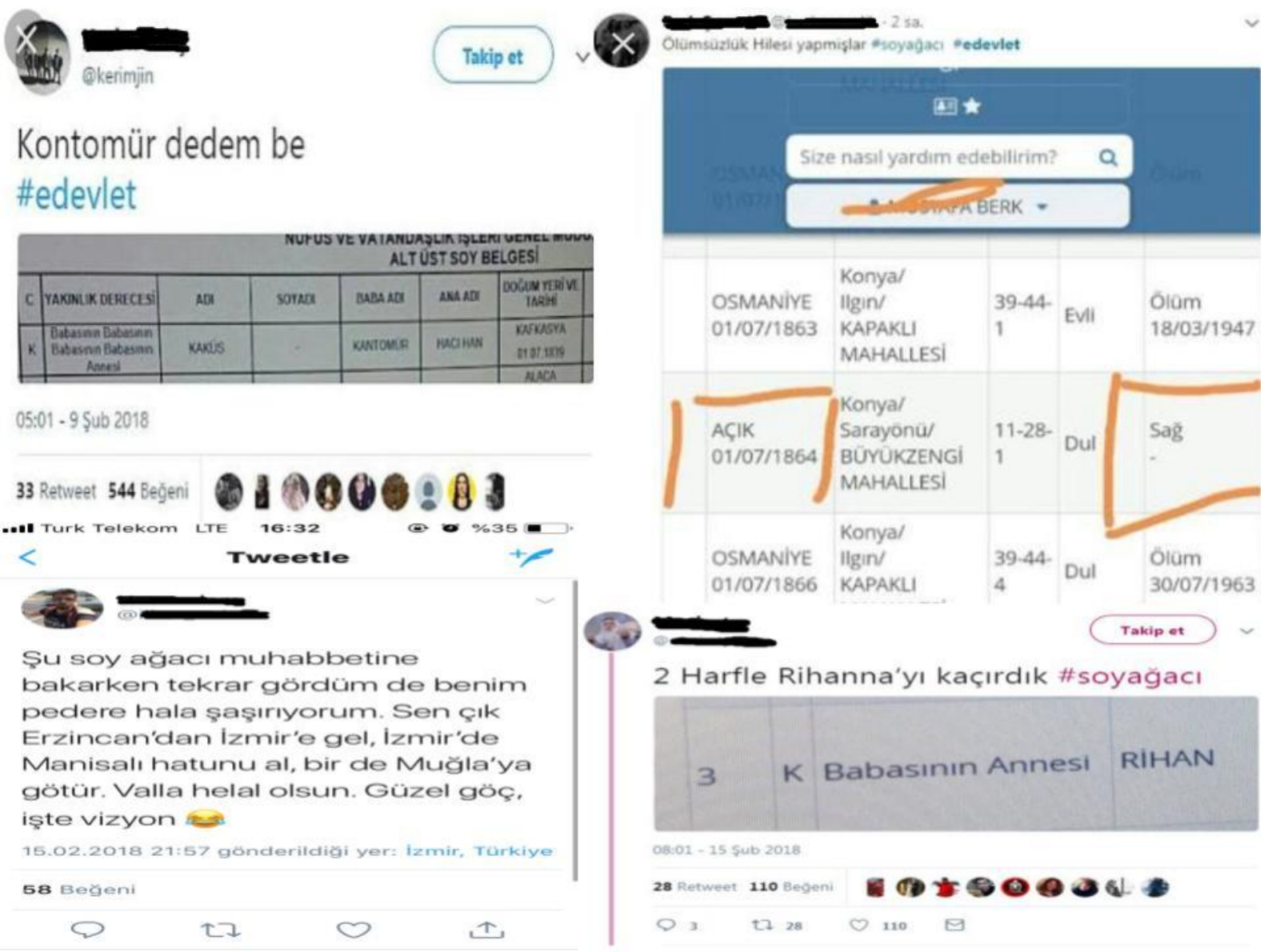

Kolaj 5: Postmodernitede Cümbüşü Bozan Kaygılar Bastırılarak Cümbüşe Eklemlenirler. Soyağacı

\section{Paylaşımlarının Parodikleşmesi De Buna Katkı Yapan Cinstendi}

Soyağaçları ortaya çıktılar/saçıldılar ve bu nedenle de bir anlamlılık kategorisi inşa etmeksizin postmoderniteye özgü şekilde yok olup gittiler. Nitekim soy kurgusu da sadece bu gerçekliğe uygun bir çıktıyla gündemleşmiş oldu. Çünkü geç modern bireylerin hayatı, 'ölümsüzlüğün evcilleşmesine' özgü bir akış halinde sürdügü için, ölümle ilgili hiçbir deneyimlemeye açık değildir. Atalar kültü bir ölüm geleneği olarak, bireyin ölümü deneyimleme sürecine açık bir temayı içinde barındırması nedeniyle (cümbüşü bozması nedeniyle) itici hale getirilmişti. Bu nedenle geç modern bireyler ölüm korkusunun ciddiyetini gündelik şenliğe içkin parodiyle bastırarak, gündelik akışın iz bırakmayan ritmine dahil etmiş oldular. 
Başka bir ifadeyle de yaşananlar trajik olanın baskılanması ya da trajik olanın parodikleşmesi anlamına gelmektedir. Bir bakıma ifade ediliş şekli yer değiştirerek ve hedef saptırarak (tıpkı kilo ve şişmanlık özelinde olduğu gibi) dışa vurulmaktaydılar. Her halükarda yaşanan süreç, özelleştirilmiş korkuların dışa vurumundan başka bir şey değildi ve yaşananlar maske takan haliyle karşımıza çıkmışlardı. Anlamsızlığ açık eden söylemler de bu türden dişa vurum biçimleri niteliğindeydiler.

Kişisel emniyetle ilgili bütün saplantılı kaygıların temelinde yatan varoluşsal korkuyu bedenin ölümlülüğü, amansız ve durdurulamaz bir biçimde hiçliğe batması besler... Asıl tehlike nihai ölüm... Gelgelelim çapanoğlu şuradadır ki ikame ya da yer değiştirmiş hedefleri vurmak olsa olsa geçici bir rahatlama getirir. Bunların hiçbiri korkunun asıl nedeninin büyüklüğüne erişemez... Korkuların özelleştirilmesi kendi kendini idare ettirici bir kapasiteye sahiptir. Özelleştirilmiş korkulardan ortak davalara giden... hiçbir yol yoktur... Bu tür askılar arasında... Özelleşmiş güvensizlik bir çok maske takar, ama tıpk1 Medusa'nın yüzü gibi, ancak felç olma tehlikesi göze alınarak bakılabilecek gerçek yüzünü göstermez (Bauman, 2012a, s.54-57).

Soyağacı gündemi özelinde yaşananlar 'özerk stratejinin' bireylere sunduğu hayatın çıktıları niteliğindeydiler. Bu nedenle soyağacı gündemini üreten göstergeler başlangıçta, 'ölümün korkutuculuğunu' geçmişte bastıran yitirilmişlikleri geri çağırması ihtimalinden ötürü değerli görülmüşlerdi. Çünkü soyağaçlarının; geçicilikler üzerine kurgulanmış hayatın ortasında geçmişi, kadimselliği ve ölümsüzlüğü sunması muhtemel bir araç olma ihtimali vardı. Fakat geç modern bireylerin karşılarına çıkan soy kurgusu, çok geçmeden kendi hayatları adına bir kalıcılık stratejisi sunmayınca anlamsız şeyler olarak görünürlük kazanır hale geldiler. Aslında anlamsız olan karşılarına çıkan göstergeler değildi. Anlamsız olan şey, göstergelerin kendi gündelik hayatları adına işletilemeyecek niteliklerde araçlar olmasıydı. Bir bakıma 
karşılarına kalıcılık hissi sunabilecek bir soy zinciri çıkmıştı ama 'gelenek ötesi bireyler' özerk hayatlar yaşamalarının ürünü olarak, onlara karşı hiçbir kalıcı bağlanma stratejileri üretememişlerdi. Aslında soyağacını değerli ve güvenlik vaat edebilen bir araç haline getiren şey -Henry Morgan'ın da başta dediği gibi- oradaki "isimlerin amaçsızca sallanması" değildi. İsimler zaten amaçsızca sallanan şeylerdir. Fakat bizlere güvenlik (ve belirlenmişlikler) vaat eden ise bizlerin ona duygusal anlamdaki bağlanma stratejileridir. Geç modern (postrmodern) bireylerin söz konusu gündemde hesaba katamadığ 1 şey, bulduklarının kadimsel değeri değildi. Aslında kendi hayatlarında yitirdikleri geçmişin, geleneğin ve bağlanma stratejilerinin kendisiydi. Nitekim aşağıdaki paylaşımlarda olduğu gibi pek çok paylaşım türü, soyağaçlarındaki isimleri amaçsızca yapılan salınımlar olarak yorumlayıp, kendi hayatları adına bir güvenlik vaadi olarak görmediklerinin anlatısıdır. Hatta bunun da ötesinde bilakis isimlerin kendisindeki amaçsızlığı kendi hayatlarındaki amaçsızlığa karşılık gelebilecek hale dönüştürerek, isimlerin garipliğine vurgularla bunu dışa vurmaktaydılar. Fakat nasıl ki geçmişle olan bağ kopunca, yukarıdaki örnekte olduğu gibi "Meryem" olmaktan vazgeçildiyse, garip olan isimlerin garipliği sadece onların geçmişte kalmasıyla ilgili bir durumdu. İsimler çok değişik", "kökümüz harbi ağaçmış", "isimleri hayranlıkla izliyorum", isimleri "kabul etmiyorum" türünden paylaşımlar da bu türden tepkilerin anlatısı niteliğindedir. Böylesi paylaşımlar bu nedenle içerisinde geçmişle bağın kopuşunu anlatan detaylar barındırmaktadır. Aşağıdaki paylaşım tipleri de aslında geçmişin bugünü neden belirlemekten koptuğunu, geçmişle aradaki bağın kopuş şeklini de ortaya koyarak bizlere izah edebilen türden örneklerdir. Muhtemel ki "\%100 Doğal, Gerçek Antakyalı" paylaşımı da aslında soyağacında bu türden bir şeyle karşılamıştı. Fakat pek çoklarının karşılaştığını, kamusala sürmek tercihinde bulunmayı tercih etmemekteydi. Nitekim kendisine dair özel bir faktör olarak sadece "\%100 doğal Antakyalı" olmasını belli ki kendi kişisel hikaye kurgusuna daha yakın görmüş durumdadır. Fakat kendisinin kadimsellik anlatısı olarak istikrarlı mekan kurgusunu seçtiği yerde dahi, tercihine içkin olan bir atalarla kopuşu da açık etmiş olmaktaydı. Bir bakıma bağlılık şekli dahi içerisinde kopuşu barındırır niteliktedir. 


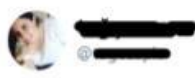

Soyağacımda çok değişik isimler var Cüldüz Devamhan İstanbulhan Ururbek. Bu arada İstanbulhan olan büyük ninem 1896'da Kafkasya'da doğmuş. Madem bu kadar İstanbul aşkınız vardı oraya göç etseydiniz. Şöyle boğaz manzaralı bi yalı fena mı olurdu 7) \#soyağacı
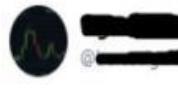

\#soyağacı

Kökümüz harbi ağaçmış.

Hakiki soyağacı bizim böyük dedeymiş

\begin{tabular}{|c|c|c|c|c|c|}
\hline Yakunlik Derecesi & Adi & Soyadı & Baba Adh & Ana Adı & Tariki \\
\hline $\begin{array}{l}\text { Annesinin Arnesinin } \\
\text { Babasinin Annesi }\end{array}$ & EMiNE & CAnLAK & BAMBU & ESE & $\begin{array}{c}\text { GEROERMAGAR } \\
\text { O1/OInI34 }\end{array}$ \\
\hline
\end{tabular}

13:09 - 15 șub 2018

2 Retweet 5 Begeni 6 \& 100

\section{Kabul etmiyonum. $9 \mathrm{dk}$}

Babasının

Annesinin

$4 \mathrm{~K}$ Annesinin KARAKIZ TOPRAK OSMAN

Babasının

Annesi

Annesinin

Annesinin

5 Annesinin MOLLA

Babasının HASAN

Babasının

Babası

Annesinin

Annesinir KARA

6

E Annesinir KARA

Annesinir

Babası

AHMET
MÜSTECAP
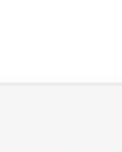


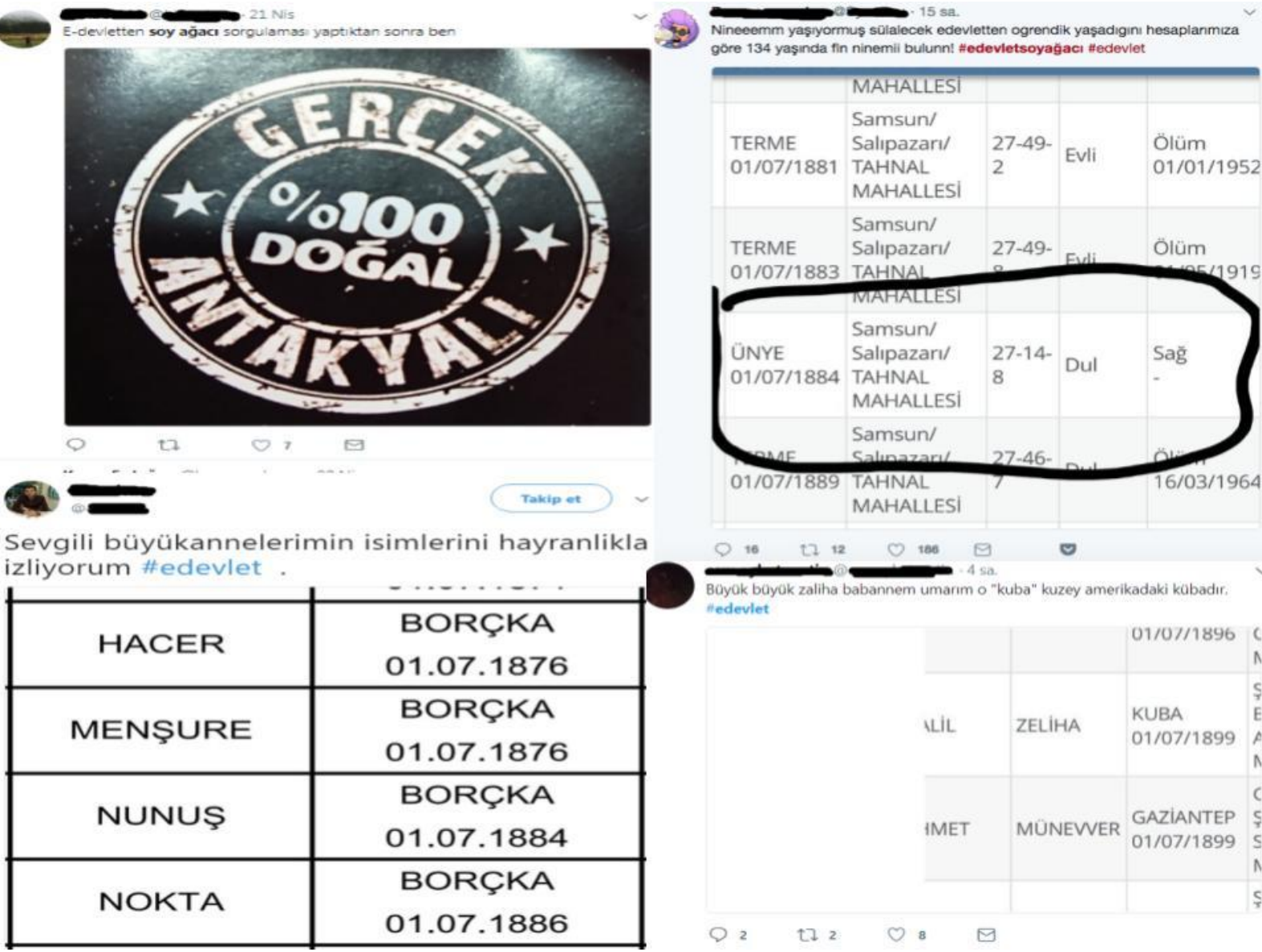

\section{Kolaj 7: Soyağaçlarından Beklenen Özelleşen Kaygılara Cevap Vermesiydi.}

Postmodern evredeki bireylerin bu türden hayatlarında 'ölümlü hale gelen şey artık ölümsüzlüğün kendisidir'. Bunun anlamı artık ölümün bir kerelik yaşanan ve onarılmaz bir eylem olmaktan çıkmasıdır. Sonlu olmanın zehri (korkusu), ölümlü ve ölümsüz her şeyin içinden çekilip alınmaktadır. Artık her şeyin çok çabuk yitip gittiği bir yaşam söz konusudur. Her gün defalarca kere sınanan bu durumun anlamı, ölümlü olmanın kendisinin ölümsüzlüğe dönüşmüş olduğunu anlatan cinstendir. Çünkü postmodern evrede hiçbir şey tamamen yok olmuyor, sadece doğrusal zaman denklemini yitirdiği ve artık döngüsel zamanda aktığ için sadece gözden kayboluyor (Bauman, 2012b, s.213-214). Postmodern dünyada aynı anda pek çok oyun oynanır ve hepsinde de kalıcılık bir sonraki duyuruya kadardır. Burada oyuncunun yapamayacağı şey, 
oyunun tamamen dışında kalmaktır ve oyunlardaki oyuncular birbirlerine hep sonsuz geri dönüş sözü verirler. Böyle bir vaat bireyleri zamanın ve ölümün doğrusallığından kurtarır. Bu da bir kez daha potansiyel bir ölümsüzlüğün (daha doğrusu ölümsüz gibi olmanın) altını çizer. Bu açıdan içinde bulunduğumuz zamanlarda kalıcı olmak yönüyle hiçbir şey ayrıcalıklı bir anlam kazanamaz (Bauman, 2017). Çünkü oyunun kalıcılığ 1 hamlelerin geçicilikleri üzerine kurulur ve dünyada olanların kalıcılık bahşetmesi bu yüzden mümkün değildir (Baudrillad, 2012; 2015). Soyağaçlarının kadim bir geçmiş olarak kalıcılık timsaline dönüşüp, yaşanılan postmodern hayatlara dair kalıcı anlatılar bahşetmekten uzak olması bu durumla yakından alakalıdır.

Sonsuzluk artık 'gelenek ötesi hale gelen bireyler' için ne geçmiş ne de gelecekten bir referans istemektedir. $\mathrm{O}$ artık sadece kısa süreli olanları sonsuza kadar sürdürmemizle alakalıdır; bu nedenle âna endeksli bir gerçekliktir. Hal böyle olunca da soyağaçları kalıcı bir duygusal bağlanmayı gerektirdiği için bu türden kısa sürelilikleri engelleme ihtimali olan bir gerçekliğe karşılık gelmektedir. Çünkü kalıcılıklar ödev ve sorumluluk yükler (Bauman, 2014; Sennett, 2012). Nitekim soyağacı gündemi özelinde yaşanan çok büyük yükselmelerin yerini iz bırakmayan gidişlere bırakması kısa süreliliklere endeksli hayatın klasik bir görünürlüğüydü. Bu nedenle postmodernitenin kişiselleşen/özerkleşen hayatlara özgü tarihselliklere aykırı bir gerçeklik niteliğinde değildi. Çünkü gelenek ötesi hale gelen postmodern bireylerin kendi ölümlerini kurgulamaktan uzaktaki hayatları, geçmişin ölümü karşılama şekillerini kendi yaşadıkları hayatın pratiklerine entegre edebilmelerinin de önüne geçmekteydi. Bu nedenle soyağacı gündeminde yaşananlar, hayatını 'ölümsüzlüğü yapısöküme uğratarak' kuran geç modern bireylerin, gündelik hayatlarını 'ölüm imgesiyle' dikey kesen bir soy kurgusuyla karşılaşmış olmaları anlamına gelmekteydi. Nitekim bu imge aslında kendi kurgusal hayatlarının akışını bozan cinstendi. Çünkü yaşananlar, kısa süreli gerçekliklere kilitlenmiş hayatın akışlarında kalıcılıkların ne kadar zor ve işlemez göstergeler haline geldiğinin altını çizmekteydi. Bir bakıma gerçekliği parodik görünümler özelinde itiraf ettiren nokta buradan kaynaklanmaktaydı. Bu yüzden dişa vurum şekilleri de "expaction and reality" (beklenti ve gerçeklik) 
türünden olmaktaydı. Bu açıdan pek çok paylaşım temelde bir 'beklenti ve gerçeklik' krizini yaşamaktaydı. Fakat bu durum temelde karşılarına çıkan gerçekliğin niteliğinden kaynaklı değildi. Arendt'in de vurguladığı gibi (2013) dünya böylesi bireyler için ölümsüzlük inancını yitirdiği için gerçekliğini de yitirmiş nitelikteydi. Ortada var olan ölüm (atalar) gerçeklikle karşılaşma biçimini bir krize dönüştüren bireylerin de tepkisi olmaktaydılar.

(Postmodern zamanda) Ortadan kaybolmuş olmakla birlikte bir türlü tamamen ortadan kalkmış gibi görünmeyen bir şeyleri sonsuza dek sürdürebiliriz. Oysa (buradaki) asıl maharet ölmeden önce ve ölmek yerine ortadan kaybolmayı başarabilmektir... (Postmodern) Özne (artık) dağınık, belirsiz ve tözden yoksun bir öznellik yararına ortadan kaybolmuştur... Ortadan kaybolmanın en büyük boyutlusu yalnızca şeylerin sanal düzeyden öteye geçmeyen bir töz değişikliğine uğraması, gerçekliğin iç içe geçmiş görünümlerinden ibaret bir şeye benzemesi değil aynı zamanda öznenin sınırsız bir bölünmeye uğramasıdır... Öte yandan şiddet, tehdit, hastalık ya da ölümün olumlu anlamda ortadan kaybolmuş oldukları ileri sürülebilir. Oysa bilinçaltında tutulan her şeyin bu şekilde bertaraf edilmesi bulaşıcı bir habis görünüme bürünerek toplumsal ve bireysel yaşamın içine sızmalarına neden olmaktadır (Baudrillard, 2012, s.14-18).

Bu nedenle aşağıdaki paylaşımlar aslında postmodern bireylerin kendi öznelliklerinin gerçeklikten kaynaklı bir çıktı olmadığının anlatıcısıdır. Hatta onların kendi bireysel kurguları geçmişten arınık yaşantıların ispatıdır. Bu paylaşımların sahiplerinin parodiye dönüşen şaşkınlıkları, içerisinde geçmişle bağını kopardığg kadar gerçeklikle de bağını koparmış bir durumun anlatımını barındırmaktadır. Çünkü onların soyağaçlarında gördükleri geçmişe verdikleri tepki, kendi öznelliklerinden müteşekkil gerçeklik halinin bozuma uğratılması olmaktaydı. Biz bakıma soyağaçlarındaki atalar onlarla karşılaşan bireylerde, 
yaşadıkları gerçeklik krizini açık eden niteliklerdeydi. Aşağıdaki paylaşım tipleri de bunun örnekleri niteliğindedir.

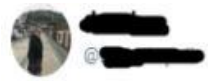

Soy ağacı sorgulama expectation vs reality

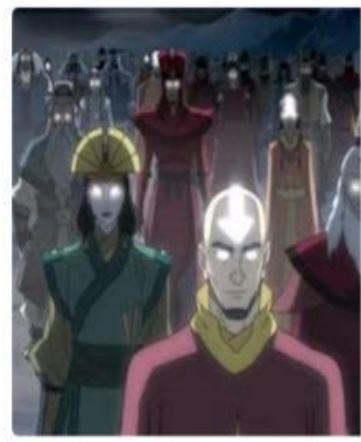

$17: 28 \cdot 15$ șub 2018

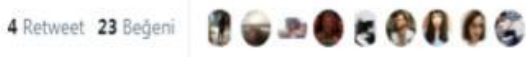

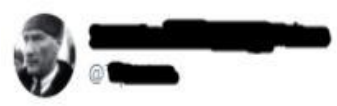

Arkadaşlar ben de isterdim havalı bir yerin göçmeni olayım \%1000 Adanalııım. Nasil bir kararlilik bu? \#soyagaci

15:15-8 Şub 2018

5 Begéni 109

Takip et
Takip et

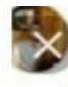

Sonunda soy ağacimı gördüm. Bir yerden göcmemiş olmamızın hayal kınikliğını yaşryonum, Aynca bizim atalan arka planda açik unutmușuz galiba $\Theta$ tedevletsoyagacı
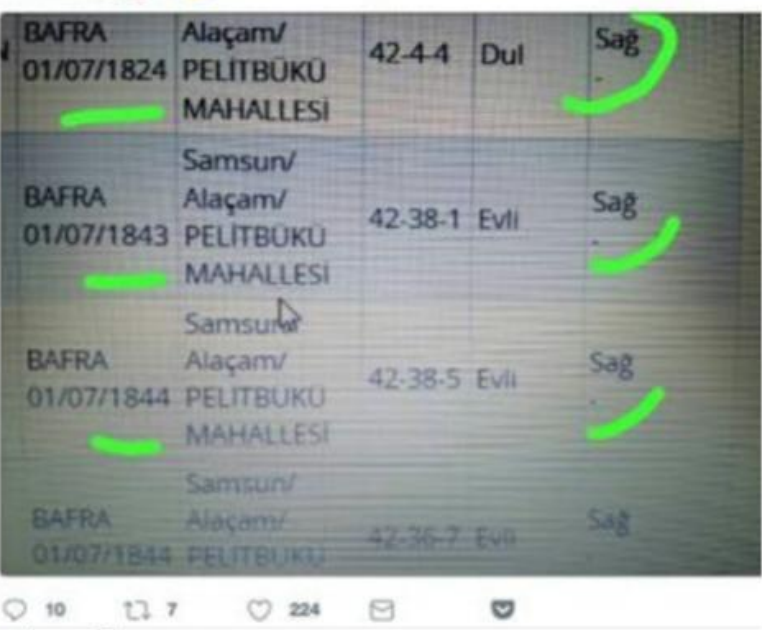

\#edevlet Ermeni ismi desen değil, Kürt ismi değil, Türk ismi değil, Kızılderiliyim galiba.

\#edevletsoyağac

\begin{tabular}{|c|c|c|}
\hline MUHi Cікі & HACI CIKI & $\begin{array}{l}\text { ADIYAMAN } \\
01.07 .1874\end{array}$ \\
\hline
\end{tabular}

\section{Kolay 8: Ölümün Bir Gerçeklik Hissi Taşımadığı Yerde Soy Kurgusu Da Bir Gerçeklik Krizine}

\section{Dönüşmüş̧ü}

Tüm bu nedenlerle de postmodern evrede karşımıza çıkan 'soyağacı gündemi' bireylerin hayatları adına kalıcı anlam ifade etmekten çok uzakta bir gösterge biçimiydi. Çünkü postmodern bireyler bugünü, geleceğin belirsizliği bağlamında yaşayan bireylerdir. $\mathrm{Bu}$ nedenle de onların bugünlerinin merkezinde gelecekleri vardır. Fakat şimdiler geleceğe bağlı hale gelirken, bugün geçmişe bağlı bir gerçeklik olmaktan uzaklaşmış durumdadır. Bourdieu'nun (1998) da dediği gibi, geleceğin belirsizliğinde şekillenen şimdiler, 
kısa süreli hayat tarzlarını gelip geçicilikler şeklinde bir bağlama eriştirdikçe, bireyin her türden kalıcılık kurgusu arayışı anlamsız hale gelmektedir. Bu nedenle 'belirsizliklerin' kalıcılı̆̆ı bizi sorumluluklar taşımaya ve ödevler yüklemeye sevk edecek ortaklıklara açık hale getirmemektedir. Hal böyle olunca postmodern evredeki 'gelenek ötesi' (post traditional) bireylerin; atalarına, soyağaçlarına, geleneklere, geçmişe ya da tarihe bağl1lıklar ilan edip bu türden söylemlere karşı sorumluluklar beslemeleri de mümkün görülmemektedir. Çünkü onlar adına bunların her biri artık anlamsız şeylerden ibaret gerçeklikler niteliğindedir. $\mathrm{Bu}$ nedenle de üretebileceği tek elle tutulur gösterge biçimi hazza endeksli tüketimsel göstergeler üretebilmesiydi. Şimdinin güvenilmez süreksizliğindeki tüketimsel davranışların haz ilkesinde karşı1ık bulmasının da nedeni benzer bir çıktıdır (Taşkaya, 2013). Çünkü geç modern hayata özgü kalıcı bağlanmaların, ödevlerin ve sorumlulukların olmayacağı tek katkı biçimi bu türden olmaktaydı. Nitekim 'özerk' bireyin hayatında her şeyin hazza endeksli tüketimsel göstergelerde karşılık bulması da bu durumun çıktısı niteliğindedir. Aşağıdaki sosyal medya paylaşımı da postmodern zamanlar için oldukça uzun denebilecek bu soyağacı gündeminin son kertede tüketimsel koşullara özgü bir şekilde nasıl yitip gittiğinin anlatımını yapan cinstendir. Çünkü gündemden geriye kalan göstergelerin haz ilkesine hizmet edebilen şekillere dönüşebilmesi ve böylesi tüketimsel bağlamlarda karşılık bulması postmodern bir gereklilik niteliğindeydi. Ancak tarihsel bağlamı açısından oldukça değerli olan 'atalar kültü' dahi, son kertede postmodern zamanların ruhuna özgü olarak bir tüketimsel bağlama karş1lık gelerek ortadan kalkmıştır. Onun varlığı, geçmişte ne kadar önemli bir araç olduğuna dikkat etmeksizin, diğer her şey gibi kalıcı bir anlatı biçimi ya da bir bağlanma üretmeksizin sadece tüketimsel bir nesnesinin parçası ilan edilmekten öteye geçememişti. Bu nedenle Türkiye'deki 2018'in Şubat ve Mart aylarında yaşanan soyağacı gündemi bireylerin atalar kültüne dair yaşadığı postmodern gerçeklikleri detaylandıran önemli bir 'örnek olay niteliğindeydi. 


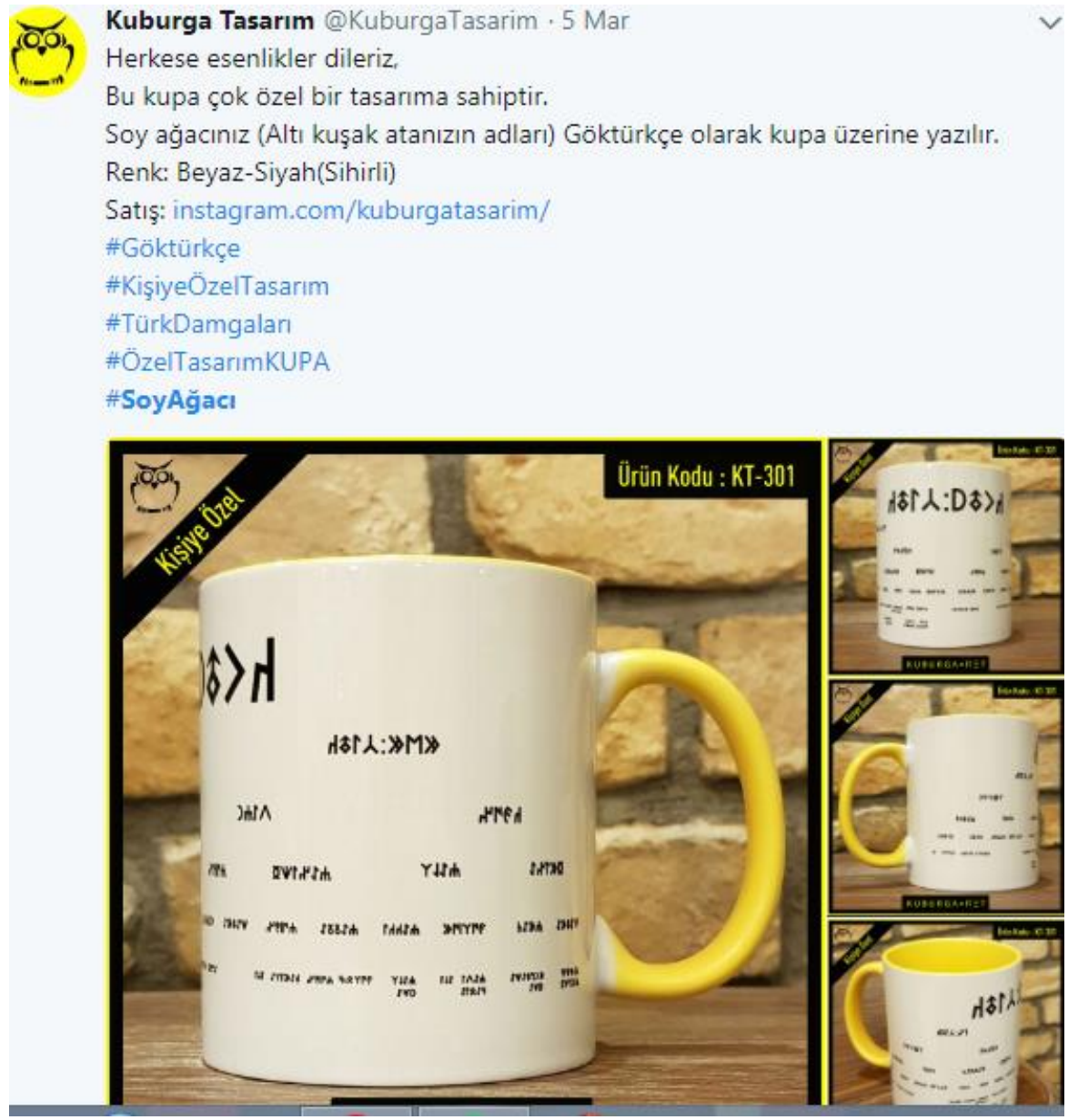

Resim 3: 'Uzun' Soyağacı Gündeminden Geriye Kalan Göstergeler Bağlanmalar, Sorumluluklar Ve Ödevler Üretmek Yerine, Diğer Her Şey Gibi Hazza Endeksli Tüketim Nesnelerine Dönüşmüşlerdir. İz Bırakmayan Hayatın Ânlara Endeksli Akışını İtiraf Edercesine. 


\section{SONUÇ YERINE}

Ölüm, modern öncesi zamanlarda uhrevi bir nitelikteydi ve bireyin kendisini aşkın gerçekliklere eklenebilmesinin yegane aracıydı. Bir bakıma birey büyük bir soy kurgusunun 'soyağacındaki' parçası olarak, kendisini ölümsüzlük stratejilerine bağlayan gerçekliğe açık hâle getirmekteydi. Ayrıca yaşanılan fani dünyadaki hayat ancak ölümle birlikte son bulduğunda bireyin uhrevi bir sonsuzluğa eklemlenmesi mümkün olmaktaydı. Bu yönüyle geleneksel (premodern) evrede 'ölüm evcildi' ve uhrevi misyonu olduğu için geçmişi bireylerin hayatlarında değerli hale getirmekteydi. Premodern bireyler bu açıdan atalarına, geleneklere, tarihe, geçmişe ve dolayısıyla 'soyağaçlarına' büyük anlamlar yükleyebilmekteydiler.

Modern evrede ise 'ölüm yapısöküme uğratılarak vahşileşmişti'. Çünkü ölüm bireyleri uhrevi bir geçmişe eklemlemiyor, aksine onların kendi yapıp ettiklerinin sonucunda yaşanan bir süreç olarak görülüyordu. Ayrıca modern zamanlar için 'gelecek' -milliyetçiliklerde ve ideolojilerde olduğu gibi- dünyevi bir proje haline getirilmişti ve bireylere ideal zamanlar olarak sunuldular. Bireyden istenilen şey ise -tıpkı premodern evrede olduğu gibi- bugünü ertelemesiydi. Fakat kendisinden ayrıca istenen şey vaat edilen zamandaki 'dünyevi idealler' için bir katkı yapmasıydı. Artık vaat edilen zaman, yeni projeler bağlamında (devrimlerde ve antiemperyalist mücadelelerde olduğu gibi) bu dünyanın sınırları içine çekilince önemli olan şey ona erişebilmek olmuştu. $\mathrm{Bu}$ nedenle ölüm modern evrede yapısöküme uğratılan haliyle, tüm uhrevi anlamından arındırıldığı için kişisel yükümlülük alanına hatta 'suça' dönüştürülmüştü. Çünkü vaat edilen gelecek (ya da mutluluk) dünyevi bir projeydi ve ona erişebilmek adına bu dünyada mümkün olabildiğince kalabilmek gerekiyordu. Fakat bu türden projeler, geleneksel evredeki dar birliktelikleri (soy, klan, akraba vb.) aşkın projelerdi. Bireyleri içine çeken totaliteler daha çok 'hayali kurgulara' karşıllık gelebilen ulus, millet ve ideoloji gibi geniş birliktelik biçimleri olmaktaydı. Modern kurgunun içinde geçmiş/tarih hâlâ etkin bir araçtı ve hâlâ gerekli bir söylem kategorisi niteliğindeydi. Fakat premodern evredeki gibi net, somut gösterge ve semboller (soyağaçları mukabilinden) üzerinden işlememekteydi. Bu evredeki en yaderk yer aileydi ama o da her türden gelenekten (geçmişten) arındırılmış ve inşa edilen projeye katkı sunması 
gereken ama soyağacı gibisinden kurgulara bağlanmayan 'çekirdek' bir nitelikteydi. Ailenin çekirdek hali onu hayali kurgulara bağlayabiliyordu ama gelenek mukabilinden şeylere asla bağlayamıyordu.

Modern evre ayrıca geleceğe ait temalar üretirdi ama gelecekleri mümkün kılan şeyleri ise bugüne endekslemekteydi. Fakat modern dünyadaki projelerde ibre geleceği gösterse de bugüne bağlı olan vaatlerin geçmişle bağı hâlâ sürmekteydi. Gelecekte vaat edilen ideal zamanlar için bugün çok değerliydi fakat bugünü mümkün kılan kodlar geçmişin referanslarında anlamlı hale gelebilmekteydi. Ama modernitenin yüzü hep geleceğe dönüktü ve zaman gelecekteki ideal evreye göre tavizsiz bir şekilde tasarlanmaktaydı. Bu yüzden modernitede zaman çizgisel şekilde tasarlanıyordu. Hedefleri (ibresi) vardı ve bu hedefler boşluk kabul etmez nitelikteydi. Fakat postmodern evreye gelindiğinde öncelikle 'ölümsüzlük yapısöküme' uğradı. Bu da postmodern bireyler için 'ölümsüzlüğü evcilleştirmiş̧' oldu. Çünkü postmodern evrede hayat artık ne uhrevi bağlama sahipti ne de ibresi olan geleceğe. Bu evrede zaman eşit anlardan oluşan kısa süreliliklerin (vadesizliklerin) ve belirsizliklerin ürünü olan bir akış haline geldi. Bu yüzden burada 'projelerden', belirlenmiş ve hedeflenen net bir gelecekten bahsetmek mümkün değildir. Her an birbirine herhangi bir üstünlüğü olmayan diğer anlar kadar değerlidir.

Postmodern (geç modern) evrede zamanı kısa parçalara bölen anların her biri klasik bir ölüm ya da sona açık hale gelememektedir. Ölümün gerçek anlamından arındırılmış son yaşayan hayatlar 'potansiyel bir sonsuzluk' hissi üretmektedirler. Bunun anlamı, özerkleşerek hem gelecekten hem de geçmişten arındırılan hayatların âna endekslenen koşulları yaşamak zorunda kalmasıdır. Bu nedenle yaşam, ölerek son bulmayan kısa süreliliklerin kalıcılığında (miadını doldurmak anlamındaki ölümü deneyimleyemediği için) yalancı bir ölümsüzlük hissini bireye yüklemiş oldu. Öyle ki postmodern evrede ölüm, yok olmak anlamında değil, gözden kaybolmak (yitip gitmek) anlamına büründü. Hatta bunu yaparken ölümsüzlüğü de içine çekmiş oldu. Fakat ölümsüzlük postmodern bireylerce ne yok edilen ne de erişilebilen bir şeydir. Böyle bir hayatta hiçbir kalıcı kimlik biçimi değer yüklü gerçeklik haline gelemeyince, kimliklerin birlikteliğinde anlamlı 
hale gelen ortaklıklar anlamsız şeyler haline geldiler. Bu nedenle hayat totalitelerin yüklediği her türden sorumluluğu değersiz ve anlamsız gördüğü için; geçmiş, gelenek, tarih ve doğal olarak da 'soyağac1' anlatıları tamamen değersiz hatta anlamsız şeyler haline geldiler.

Gelenek ötesi özelliklere sahip postmodern bireyler ölümlülügün hayaletini kendi gündelik hayatlarından kovdular ama bunu yaparken hayatın gerçekliğini ve gerçeklik deneyimlerini de yok etmiş oldular. Artık hayat ciddiye alınması mümkün olmayan 'kısa süreliliklerin' (sorumluluk yüklenmeyen gelip geçiciliklerin) çatışmasına dönüştü. Başka bir ifadeyle bireyi diğerlerine bağlayan kalıcılık ve istikrarın (geçmiş ve geleceğin) yok olduğu bir düzlem edindi. Bu nedenle sorumluluk ve ödevler gerektiren atalar ya da soyağaçları, yaşanan hayatlara dair nitelikli göstergeler olmaktan uzaklaştılar. Çünkü postmodern hayatlarda gündelik ritim zaten bir cümbüş niteliğindedir ve kalıcılıklar ise aksine ciddiyet, sorumluluk ve ödevler ister. $\mathrm{Bu}$ nedenle de cümbüşe açı hayatta geçmişe ve atalara bağlanmak postmodern bireylerin kaldırabileceği türden sosyal yükler değildir.

Bu bağlamıyla 2018'in Şubat ve Mart aylarında yaşadığımız 'soyağacı gündemi' bireylerin gündelik hayatı kurma stratejilerine dair yaşadığı büyük değişmenin anlatıcısı niteliğindeydi. Çünkü postmodern hayatların ne gibi gerçekliklere karşıllık geldiğini anlatabilen bir gündemdi. Postmodern bireyler her türden totaliteye, geçmişe ve geleceğe karşı duyarsız bir hale geldiler. 'Radikal bireyselleşme' onlar için artık kalıcı bir hayat tarzı oldu. Postmodern hayat, ortaklıkların (ve soyağacı kurgularının) işlevsizleşmesi nedeniyle, bireylerin yalnızlıkları etrafinda şekillenen bir duygusal yitim sürecine dönüştü. Bu nedenle 'soyağacı' gündemi ilk ortaya çıktığında, 'ontolojik güvenlik' bağlamında yitirilmiş olanların elde edilebilmesi ümidine dayalı olarak bireylerce büyük ilgi görmüştü. Bu büyük ilginin nedeni; kısa sürelilikleri aşamayarak belirsizlikler, istikrarsızlıklar ve güvensizlikler içinde savrulan hayatlara istikrar ve kalıcılık vaadi sunabilme umudundan kaynaklanmaktaydı. İlk tepkinin bu kadar büyük olmasının nedeni, yaşanan 'radikal bireyselleşmenin' ürünü olan anlamsızlıkların üstesinden gelinmesine yardımcı kadim bir araç olma ihtimaliydi. Çünkü 
karşılaşılanların, postmodern hayattaki baskılanan ölüm korkusuna dair önemli referanslar üretebilme ümidi söz konusuydu. Çok geçmeden söz konusu paylaşımlar, ânâ endekslenen şimdiler etrafında kurgulanan hayatlar için, herhangi bir anlamının olmadığı anlaşılan semboller haline dönüştüler. Bu açıdan bireylerin yaşadığı duygusal yitimler nedeniyle soyağaçlarına (atalara) karşı, göstermeleri gereken ciddiyet koşulu tarihselliğe uygun koşullarda oluşmadı. Çünkü bugünü anlamlı kılan geçmişin verdiği kadimselliğe özgü ontolojik güvenlik hissi ve duygusal bağlanma becerileri yitirildiği için bireyler bu duygulara aşina olma yeteneklerini köreltmişlerdir. Bu açıdan postmodern bireylerin atalarıyla (soyağaçlarıyla) böylesi bir şekildeki karşılama biçimi, kendi geçmişlerine dair var olan büyük bir yabancılaşma şeklini görünür hale getirmiştir.

Bu bakımdan sosyal medya bağlamında parodikleşen 'soyağacı gündemi', toplumsal hayatın kalıcılık ve istikrar vaadi sunan ortaklıklarına dair düşünülünce bir 'trajediye' karşılık gelmekteydi. Söz konusu gündeme dair yaşananlar her türden kalıcılık, istikrar ve ortak bir kader algısı olarak birlikteliklerin, postmodern hayatların anlam kurgusunda ne kadar değersiz şeyler haline geldiğinin anlatımını yapabilen cinstendi. $\mathrm{Bu}$ durumun daha derin anlamı ise; hayata dair tüm kalıcılık stratejilerinin, geleneklerin ya da anlatılarının ne şekillerde işlevsizleştiğinin daha açık hale gelmesidir. Bir bakıma 'ölümsüzlük hissini' her gün deneyimleyen bireylerin özerkleşen hayatlarında her türden 'ölümsüzlük stratejisini' ne kadar değersiz hale getirdiklerinin dışa vurumuydu. Ölümü gerçek anlamında deneyimlemekten uzaklaştıkları için 'ölümsüzlük hissi' yaşayanlar, bu yüzden ölmüşlerin sunduğu 'soyağacı' gibi sembollere kalıcı hayat stratejileri bağlamında bakamamışlardır. Çünkü kendi hayatları kısa epizotlara endeksli anlar etrafında kurgulanmaktadır. Bu nedenle postmodern bireylerin hayatında tarih, gelenek, atalar, soy ya da şecere anlamlı gerçeklikler olmaktan uzaklaşmışlardır. Nitekim postmodern zamanları yaşayan radikal bireyler bu bağlama uygun olarak 'soyağaçlarına' karşı büyük bir yükselme yaşadılar ve çok geçmeden onu kendi hayatları adına anlamsız görerek 'gözden yitip gitmesine' müsaade ettiler. Bu yönüyle gündem yaşanırken görüntüsü parodik olan durum, sosyolojik derinliği açısından kalıcı birliktelik biçimlerinin anlamını 
yitirmesi olarak ele alınabilecek 'trajik' bir gerçekliğe karşı gelmekteydi. Çünkü yaşananlar yalnılaşan egoların ürünü olan, savaş meydanlarındaki 'radikal bireyselleşmelerin' dışa vurumuydu. Bu açıdan 2018'in Şubat ve Mart aylarında yaşananlar -sosyal medyanın genel görünürlüğünün aksine- aslında bir komedi türü olmaktan ötedeydi. Yaşananlar bir bakıma her türden toplumsal ortaklık biçiminin sonunun ne boyutlarda yaşandığına dair 'trajikomik' bir anlatımın gündelik hayattaki görünürlüğüne dair örnek bir vaka niteliğindeydi. Parodik olanlar ise sadece onun görünürlüğüydü. 


\section{SUMMARY}

In traditional societies of pre-modern era, the strategies constituting life used to be built on the past; thus, concepts like ancestry, lineage, genealogy or family tree used to be much more significant. Moreover, since such concepts allow mortal individuals to become a part of a reality beyond them, they used to integrate mortal individuals into immortal strategies. Such entities which invite individuals to act up so as to 'leave a mark' in the societal commonalities also presented meaningful stability narratives about life. However, the associations of late modern (postmodern) individuals have gradually become lives in which 'individualistic strategies' are prominent. Since such a way of life is built on the uncertainties of the future, no form of traditionalism (the past) or permanent narrative styles is meaningful for the 'post traditional individuals' in that phase. The more what is experienced to this end is indexed to the efforts of coping with the uncertainties of the future, the less they have trivialized the knowledge and references respecting the past overtime. The lives that cut ties with their past experience estrangement from their pasts by atrophying their expectations of 'archaism' and 'transcendency' . The society has shown deep interest to the family tree service which has been made accessible not long ago through 'e-Government' in Turkey, and a huge agenda has been generated through social media. The study has tried to examine the agenda as a 'case study', and interpret the emergent public behaviour as an expression of the 'uncertainties and fear of death' in the late modern era. Therefore, this study has tried to make a theoretically grounded examination of death and the past (the culture of ancestors) in terms of 'uncertainties and fear of death' in the light of the current agenda of recent times. The setup of the research has been maintained with a qualitative method with a concern of building theoretical foundations to a 'case study'. Online posts regarding the aforesaid agenda have been collected with 'purposeful sampling' technique, and by getting suitable data set they have been tried to be examined phenomenologically with regards to their reasons. 


\section{KAYNAKÇA}

Aires, P. (2015). Batı'da Ölümün Tarihi/ İstanbul: Everest Yayınları.

Anderson, B. (2017). Hayali Cemaatler. İstanbul: Metis Yayınları.

Arendt, H. (2013). İnsanlık Durumu (Seçme Eserler 1). İstanbul: İletişim Yayınlar1.

Balandier, G. (2010). Siyasal Antropoloji. İstanbul: İş Bankası Kültür Yayınları.

Baudrillard, J. (2012). Neden Her Şey Hâlâ Yok Olup Gitmedi?. İstanbul: Boğaziçi Üniversitesi Yayınevi.

Baudrillard, J. (2015). Şeytana Satılan Ruh ya da Kötülü̆̆̈̈n Egemenliği. Ankara: DoğuBatı Yayınları.

Bauman, Z. (1999). Çalışma Tüketicilik ve Yeni Yoksullar. İstanbul: Sarmal Yayınevi.

Bauman, Z. (2011). Postmodern Etik. Alev Türker (Çev:), 2. Baskı, İstanbul: Ayrıntı Yayınları.

Bauman, Z. (2012a). Siyaset Arayışı. İstanbul: Ayrıntı Yayınları.

Bauman, Z. (2012b). Ölümlülük, Ölümsüzlük ve Diğer Hayat Stratejileri. İstanbul: Ayrıntı Yayınları.

Bauman, Z. (2013). Yaşam Sanatı. İstanbul: Versus Kitap.

Bauman, Z. (2014). Parçalanmış Hayat: Postmodern Ahlak Denemeler. İstanbul: Ayrıntı Yayınları.

Bauman, Z. (2015). Bireyselleşmiş Toplum. İstanbul: Ayrıntı Yayınları.

Bauman, Z. (2016). Cemaatler: Güvenli Olmayan Bir Dünyada Güvenlik Arayışı. İstanbul: Say Yayınları.

Bauman, Z. (2017). Akışkan Modernite. İstanbul: Can Sanat Yayınları.

Beck, U. (2011). Risk Toplumu: Başka Bir Modernliğe Doğru. İstanbul: İthaki Yayınları.

Bourdieu, P. (1998). Acts of Resistance. Cambridge: Cambridge Polity Press.

Coulanges, F. De. (2011). Antik Site. Ankara: Epos Yayınları.

Creswell, J. W. (2016b). Araştırma Deseni: Nitel, Nicel ve Karma Yöntem Yaklaşımları. Ankara: Eğiten Kitap.

Davey, L. (2009). The Applicaion of Case Study Evaluations. Elementary Education Online.

$\mathrm{SAD} / \mathrm{JSR}$

Cilt / Volume 22 Sayı / Number 2 
Deleuze, G., Guattari, F. (2017). Anti Odipus: Kapitalizm ve Şizofreni 1. Balıkesir: Bilim ve Sosyalizm Yayınları.

Feuerbach, L. (2015). Tanrıların Doğuşu. İstanbul: Say Yayınları.

Frazer, J. G. (2017). The Belief in Immortality and the Workship of the Dead. Vol. 1, New Jersey: Pinnecle Press.

Giddens, A. (2004). Modernliğin Sonuçları. İstanbul: Ayrıntı Yayınları.

Giddens, A. (2010). Modernite ve Bireysel Kimlik: Geç Modern Çăgda Benlik ve Toplum. İstanbul: Say Yayınlar1.

Heidegger, M. (2011). Varlık ve Zaman. Çev. Kaan H. Ökten. (2. Bask1). İstanbul: Agora Kitabevi.

Hauzinga, J. (1997). Ortaçağın Günbatımı. Ankara: İmge Kitabevi Yayınları.

Husserl, E. (2010). Fenomenoloji Üzerine Beş Ders. Ankara, Bigesu Yayınları.

Hobsbawn, E. (2001). Tarih Üzerine. Ankara: Bilim ve Sanat Yayınları

Kellehear, A. (2012). Ölümün Toplumsal Tarihi. Ankara: Phoenix Yayınları.

Kerrigan, M. (2018). Ölümün Tarihi. Ankara: Paris Yayınları.

Kierkegaard, S. (2004). Ölümcül Hastalık Umutsuzluk. Ankara: Doğu Batı Yayınları.

Levinas, E. (2014). Ölüm ve Zaman. İstanbul: Ayrıntı Yayınları.

Lyotard, J. F. (2014). Postmodern Durum. Ankara: Bilgesu Yayınc1lı.

Maxvell, J. A. (2005). Qalitative Research Design: An Interactive Approach. Sage Publication, London.

Merriam, S. B. (2013). Nitel Araştırma: Desen ve Uygulama. Ankara: Nobel Yayıncılık.

Miller, M. (Yönetmen). (2014). The King of Columbus Circle [Televizyon Dizisi]. Forever içinde. Bölüm: 15. ABC.

Sennett, R. (2011b). Yeni kapitalizm kültürü, İstanbul: Ayrıntı Yayınları. 
Sennett, R. (2012). Karakter Aşınması: Yeni Kapitalizmde Işin Kişilik Üzerindeki Etkileri. İstanbul: Ayrıntı Yayınları.

Spellman, W. M. (2017). Ölümün Kısa Bir Tarihi. İstanbul: Can Sanat Yayınları.

Taşkaya, M. (2013). Reklamda Nostaljik Unsurlar: Kimlik Vaadi ve Anlamın Yitimi, Ethos, 6(1), 1-37.

Yin, R. (2017). Durum Çalışması Araştırması Uygulamaları. Nobel Yayın Dağıtım, Ankara.

\section{Kullanılan Materyallerin Listesi}

Resim 1: Atatürk'ün soyağacına dair örnek bir paylaşım.

Resim 2: Soyağacı yükselmelerinden geriye kalan göstergeler sorumluluklar ve ödevler üretmek yerine çok geçmeden diğer her şey gibi hazza endeksli tüketim nesnelerine dönüştüler. İz bırakmayan hayatın anlara endeksli akışını itiraf edercesine.

Kolaj 1: Soyağacı gündeminde öne çıkan parodiye dair birkaçörnek

Kolaj 2: Kimlik kişisel bir mesele haline gelince komünal değeri olan göstergeler (soyağaçları) gündelik hayatlar için anlamsız hale gelmektedir.

Kolaj 3: Soyağacı parodisi kısa epizotlara bölünen hayatların dışa vurumu niteliğindeydi

Kolaj 4: Atatürk'ün soyağacının medyadaki görünürlüğüne dair bir kaç örnek.

Kolaj 5: Postmodernitede cümbüşü bozan kaygılar bastırılarak cümbüşe eklemlenirler. Soyağacı paylaşımları da buna katkı yapan cinstendi.

Kolaj 6: Soyağacı postmodern bireylerin kalıcı bağlanma stratejilerini işletemediğini açık eden cinstendi.

Kolaj 7: Soyağaçlarından beklenen özelleşen kaygılara cevap vermesiydi.

Kolay 8: Ölümün bir gerçeklik hissi taşımadığı yerde soy kurgusu da bir gerçeklik krizine dönüşmüştü. 